\title{
Lusioersily
}

\section{Deviations from aspirational target levels and environmental and safety performance:Implications for operations managers acting irresponsibly}

Wiengarten, F., Fan, D., Pagell, M., \& Lo, C. (2019). Deviations from aspirational target levels and environmental and safety performance:Implications for operations managers acting irresponsibly. Journal of Operations Management, 65(6), 490-516. https://doi.org/10.1002/joom.1032

Link to publication record in Ulster University Research Portal

Published in:

Journal of Operations Management

Publication Status:

Published (in print/issue): 02/09/2019

DOI:

10.1002/joom.1032

\section{Document Version}

Author Accepted version

\section{General rights}

Copyright for the publications made accessible via Ulster University's Research Portal is retained by the author(s) and / or other copyright owners and it is a condition of accessing these publications that users recognise and abide by the legal requirements associated with these rights.

\section{Take down policy}

The Research Portal is Ulster University's institutional repository that provides access to Ulster's research outputs. Every effort has been made to ensure that content in the Research Portal does not infringe any person's rights, or applicable UK laws. If you discover content in the Research Portal that you believe breaches copyright or violates any law, please contact pure-support@ulster.ac.uk. 
Deviations from aspirational target levels and environmental and safety performance:

Implications for operations managers acting irresponsibly

\author{
Frank Wiengarten* \\ Universitat Ramon Llull \\ ESADE \\ Barcelona, Spain \\ Frank.wiengarten@esade.edu \\ Di Fan \\ Research School of Management \\ Australian National University \\ Australia \\ Mark Pagell \\ Smurfit Graduate School of Business \\ University College Dublin \\ Carysfort Avenue \\ Blackrock \\ Co. Dublin \\ Ireland \\ Chris K.Y. Lo \\ Institute of Textiles and Clothing \\ The Hong Kong Polytechnic University \\ Hong Kong
}

* Corresponding author 


\title{
Title
}

Deviations from aspirational target levels and environmental and safety performance: Implications for operations managers acting irresponsibly

\begin{abstract}
The relationship between sustainable operations and a firm's financial performance has been an ongoing focus of operations management scholars. Previous literature has extensively explored the impact of acting responsibly on financial performance. This paper applies the behavioral theory of the firm and prospect theory to assess the muchneglected reverse relationship, exploring whether a firm's relative aspirational financial performance impacts its likelihood of acting irresponsibly. Furthermore, we explore whether operational slack in the form of capacity, productivity, and inventory attenuates a firm's likelihood of acting irresponsibly when its actual financial performance deviates from its aspirational level. We use a matched pair design with privately held manufacturing firms in the United Kingdom who acted irresponsibly matched with similar firms who did not act irresponsibly. While most firms do not act irresponsibly, we find that the further a firm moves (positively or negatively) from its aspirational level of financial performance, the more likely it is to act irresponsibly. The results also indicate that slack generally does not prevent managers from acting irresponsibly, especially when performing relatively well. This study contributes to the sustainable operations literature and provides important theoretical, managerial, and policy implications.
\end{abstract}

\section{Keywords}

Aspiration level, problemistic search, behavioral theory of a firm, sustainability, hubris 


\section{Introduction}

The operations management literature has for decades explored how firms can become more environmentally and socially sustainable (e.g., Klassen and Whybark, 1999). Yet, a small but significant number of firms continue to take the risk of neglecting their environmental and social responsibilities (Pagell and Gobeli, 2009; Huq et al., 2016; Wilhelm et al., 2016; Jacobs and Singhal, 2017). Recent examples include sweat shop labor in Zara's supply chain and Mattel selling toys coated in toxic paint (Burgen and Phillips, 2011; Wilhelm et al., 2016). The negative implications of acting irresponsibly, which include tarnishing a firm's reputation, lawsuits, financial losses, and increases in the cost of capital, are well-known and apparent (Lange and Washburn, 2012), yet irresponsible behavior continues.

Researchers in strategic management, finance, and marketing have explored irresponsible behavior from multiple perspectives, such as producing unsafe consumer goods, misleading marketing practices, and engaging in financial misrepresentation. Operations management research generally addresses these issues indirectly by including environmental and social concerns in research examining more responsible or sustainable behavior (Pagell and Shevchenko, 2014). The operations management literature has, with a few notable exceptions (e.g., Jacobs and Singhal, 2017), not explored the drivers of irresponsible behavior. Our research focuses on irresponsible behavior by exploring the role of operations management in violating or breaching environmental and safety regulations. 
The behavioral theory of the firm (BTF) appears to provide an important explanation as to why some companies continue to behave irresponsibly. The BTF proposes that decision makers evaluate the need to change existing routines by comparing organizational performance with a target or aspiration level (March and Simon, 1958; Cyert and March, 1963; Desai, 2016). Irresponsible behavior could result when performance is not at aspirational levels. The BTF posits that the further a firm performs above or below their aspirational level, the more likely they will be to engage in risky behaviors, whether that risky behavior is changing the strategy; investing in new technology; or breaching environmental, health, and safety (EHS) regulations (e.g., Harris and Bromiley, 2007). For firms performing below their aspirational levels this is intuitive; their performance is (relatively) poor, and they need to catch up to avoid going out of business. In addition to being intuitive, this prediction is in line with other theories of firm or individual risk taking (Hoskisson et al., 2017).

However, that firms performing above their aspirational levels would take similar risks is counter-intuitive. While this prediction does find some empirical support (e.g., Mishina et al., 2010), there are multiple explanations for these findings. The first is that firms performing above aspirations are hubristic and believe they can get away with actions others cannot (e.g., Tarakci et al., 2018). The second is that firms performing well, especially those doing extremely well, believe that future performance is likely to decrease, and hence they take extreme measures to avoid this loss (e.g., Mishina et al., 2010). The hubris and loss aversion explanations are both about framing future outcomes. However, they are also somewhat contradictory. Hubris is a form of 
overconfidence about future outcomes, while loss aversion is a form of pessimism about the future. In addition, the prediction that firms that are doing well will engage in risky behavior conflicts with other theories of risk taking (Hoskisson et al., 2017), such as prospect theory (PT), which posits that individuals (e.g., managers) are risk seeking when facing losses and risk averse when facing the prospect of potential gains (Kahneman and Tversky, 1979).

This disputed space has not been addressed at the operational level. Thus, we use the BTF and PT to explore the environmental and occupational health and safety aspects of irresponsible behavior to answer the following question: (1) How does a company's performance relative to its aspirational level of performance affect its decision to breach environmental and safety regulations?

In addition, we note that the choice of whether or not to breach regulations is likely a function of options. For operations managers options often come in the form of slack, and slack has been shown to predict the likelihood of accidents (e.g., Wiengarten et al., 2017). If the predictions of the BTF apply to breaching environmental and safety regulations, then slack may explain why. Specifically, the presence of slack would be indicative of options. Firms performing below aspirations would explore breaching only if they had no other options, e.g. no slack. Similarly, firms performing above aspirations only breaching when slack is absent fits with the loss aversion prediction; firms with no slack perceive that breaching is the only option available to meet their future performance goals, and therefore a small number of them breach. However, if firms performing above aspirations breach even when they have slack, hubris would 
seem to be a more reasonable explanation for their irresponsible action. Thus, we also address the following research question: (2) Does the availability of resources controlled by operations managers reduce the chances of irresponsible behavior in situations when performance deviates from the aspirational level? To explore these research questions, we compiled secondary data collected in the United Kingdom (UK) from private manufacturing firms. We conceptualize aspirational performance in terms of a firm's relative performance compared to both industry and its own historical performance (Cyert and March, 1963; Harris and Bromiley, 2007).

We extend previous research in several critical ways. First, we add to the nascent body of research that explores the role of aspirational or relative performance in irresponsible behavior from the perspectives of the BTF and PT simultaneously. Second, our focus is on how operations managers respond to performance that is either above or below aspirational levels. The irresponsible behavior examined in this research is the breaching of EHS regulations. Safety and environmental management both occur in the operational sphere, meaning that the actions of operational managers would be directly related to breaches of EHS regulations, while the same managers are unlikely to have a direct role in behaviors such as misstating financial reports. Finally, by exploring the decision to breach simultaneously with relative performance and slack we provide greater theoretical clarity as to why firms breach, especially when performing well.

The vast majority of firms do not breach EHS regulations. However, our results indicate that the further a firm moves (positively or negatively) from its aspirational 
level of financial performance, the more likely it is to be one of the small number of firms that do breach EHS regulations. The results also indicate that the presence of slack generally does not prevent managers from acting irresponsibly, especially when performing relatively well. This study contributes to the sustainable operations literature and provides important theoretical, managerial, and policy implications.

\section{Literature review}

Behavioral theories suggest that individuals (e.g., Kahneman and Tversky, 1979) and firms (e.g., Cyert and March, 1963) perceive performance in relative, not absolute, terms. And there is a robust debate on how gaps between relative and actual performance impact decision making (e.g., Tarakci et al., 2018). This research is largely framed with the BTF and PT (Kahneman and Tversky, 1979; Shimizu, 2007; Mishina et al., 2010). Conceptualizing financial performance in relative terms allows us to explore why we continuously observe cases of firms that are acting irresponsibly both when performing well or poorly in absolute terms.

PT (Kahneman and Tversky, 1979, Tversky and Kahneman, 1992) proposes that individuals frame gains and losses relative to a reference point (that need not be zero) and that losses have more salience than gains. Hence individuals are risk averse when they perceive a future (relative) gain and risk seeking when they perceive a future (relative) loss. In PT, the reference point is determined by the individual.

The BTF also conceptualizes performance as relative, but in this case the reference point, or aspiration, is determined by the firm through historical and social comparisons 
(Mezias et al., 2002). Historical aspirations compare a firm's present performance to its own past performance. Social aspirations compare a firm's present performance to the performance of its industry peers (Harris and Bromiley, 2007).

The choice to breach (or not) is a mixed gamble in that the decision has the possibility of both gains and losses (Martin et al., 2013). This is different from a pure gamble, where the outcomes will be either win/win or lose/lose. The possible outcomes involved in the breaching decision are the certain costs of compliance, the uncertain costs of being found in breach for non-compliance, and the uncertain gains or savings from non-compliance if not caught.

Given the rarity of breaches, compliance is assumed to be the base or status-quo state for most firms. Compliance has a cost, but that cost is (much) lower than being found in breach. The likelihood of being caught while out of compliance is unknown. However, only a very small percentage of firms (2.5\% in our sample in any given year) are found in breach.

Our data include safety breaches and environmental breaches. The process of being found in breach is similar for both, hence for illustrative purposes we explain how a firm would be found in breach of safety regulations in the UK. In 2017/18, 70,062 accidents were reported to the Health and Safety Executive (HSE), the HSE issued 11,522 enforcement notices, and 493 firms were found in breach (HSE, 2019).

The process of being found in breach starts with an investigation (typically of a major or fatal accident) or a random inspection. HSE inspectors and investigators assess whether the firm is out of compliance and, if so, the level of non-compliance based on 
the HSE's enforcement management model. ${ }^{1}$ Most firms that are found to be out of compliance receive an enforcement notice. There are two types of enforcement notices; a prohibition notice is served when the HSE believes there is a risk of serious personal injury that must be remedied before work can continue, while an improvement notice gives a firm a set period of time to make improvements. Finally, in a small number of cases the HSE recommends prosecution and a criminal trial. A firm or its managers that are convicted in this prosecution will have been found in breach. Prosecution is pursued in extreme cases, such as when there was fatality resulting from non-compliance, there was reckless disregard of regulation, and/or repeated or persistent non-compliance. The HSE pursues prosecution only when it believes there is a reasonable chance of conviction of either the firm or individual managers. The 493 breaches in 2017/18 were the result of 517 prosecutions.

The likelihood of being found in breach even for firms that are issued enforcement notices is very low. A firm's perception of the likelihood of being found in breach will influence whether breaching is viewed as a potential loss or gain. For hypotheses development we follow much of the PT literature and simplify this mixed gamble into a win/win or lose/lose pure gamble (Birnbaum, 2006).

A firm's decision will depend on whether they frame the prospect as a gain or a loss relative to the reference point they choose (Hoskisson et al., 2017). "A reference point is sometimes the status quo, but it can also be a goal in the future: not achieving a goal

\footnotetext{
${ }^{1}$ http://www.hse.gov.uk/foi/internalops/og/ogprocedures/index.htm
} 
is a loss, exceeding the goal is a gain....the aversion to failure of not reaching the goal is much stronger than the desire to exceed it" (Kahneman, 2011, p. 302). This framing will be a function of the perceived likelihood of being caught if the firm breaches and how much the firm perceives compliance or getting caught to cost.

This is still a simplification in that firms typically face a greater range of options than whether or not to breach. A key mechanism of the BTF is the problemistic search (March and Simon, 1958; Argote and Greve, 2007). The traditional view in the literature is that when a firm's performance deviates from its previously formed aspirational level, it starts a problemistic search for actions and practices to help return to or exceed the aspiration level. Previous research has identified multiple actions that firms have taken as a result of this problemistic search, including innovation, capital investment, changing strategic direction, and breaking the law (Harris and Bromiley, 2007; Tarakci et al., 2018). Each of these actions may entail higher levels of risk that firms are willing to take on in order to return to or exceed their aspirational level of performance (Bromiley, 1991).

Our contention is that slack could be a form of options for firms performing a problemistic search. The decision of whether or not to breach is then a function of the firm's current reference point, whether managers conceptualize the choice to be in breach and risk getting caught as an uncertain loss or uncertain gain, and the presence or absence of other options in the form of slack. We review the literature's predictions for firms performing below and above aspirations and then examine how slack might provide much needed insight into the decision to breach. 


\subsection{Performance below aspirational levels}

Prospect theory, the BTF, and intuition all suggest that firms performing poorly will be unlikely to want to protect the status quo and be more likely to take risky actions. Some of these risky actions are perfectly legitimate or even necessary for firm survival. For instance, Tarakci et al. (2018) study the choice to change strategy in the face of performance that deviates from aspirational levels. However, other risks may be inappropriate or illegal (e.g., Harris and Bromiley, 2007). In this paper we explore whether a company's performance relative to its aspirational level affects its likelihood of engaging in irresponsible and illegal behavior. We conceptualize irresponsible behavior as breaches of EHS regulations because these breaches would be mainly the result of choices made by operational managers, while other irresponsible behaviors such as financial misreporting would not be.

Managing health and safety, ensuring that hazardous materials are properly handled, and so on are key operational responsibilities. When top management concludes that performance is below aspirational performance levels, they will search for actions they can take to improve performance. For a CFO the problemistic search might conclude with the decision to misstate earnings. Simultaneously, the COO and other operational managers would also be searching for ways to make an operational contribution to bring performance back to aspirational levels. Breaching EHS regulations might present a relatively quick and easy fix for the firm's financial difficulties, especially when compared to many other levers available to operations managers, such as process improvements or investing in new equipment, which take time and/or money. Hence, a 
small number of operational managers looking for ways to help their companies return to aspirational levels of performance may do so by breaching EHS regulations.

Multiple studies have proposed a negative association between firm performance and illegal behavior. The broad argument has been that poor performance "pressures firms to find alternative sources of resources or to cut costs in ways that may not be legal" (Baucus and Near, 1991, p. 14). Research supports this supposition, and there is evidence that firms with poor absolute performance are more likely to break the law (Clinard et al., 1979), breach environmental regulations (McKendall and Wagner, 1997), and have higher accident rates (Rose, 1993).

Harris and Bromiley (2007) conducted one of the first studies exploring the relationship between relative performance and irresponsible behavior. They examined the factors that encourage a company to misrepresent its financial position. Building on the BTF they identified that organizational performance below aspirations increases the likelihood of financial misrepresentation (Harris and Bromiley, 2007). These findings also fit well within PT's predictions about individual managers seeking risk when they expect future loses.

The literature suggests that certain firms performing below aspiration can frame the choice to be in breach as a choice between compliance with a certain gain (of zero) and an uncertain but much larger gain for breaching but not getting caught. This small percentage of firms might also frame the same decisions as the choice between a certain loss (compliance) with an uncertain but greater loss (breaching and getting caught). Regardless of the framing, a small number of firms might take the risk of being in 
breach. Such firms are aware that if they get caught, the costs could be very high, but "people become risk seeking when all of their options are bad" (Kahneman, 2011, p. 279). The literature on BTF and PT both make consistent predictions that low aspirational performance can lead to risk-seeking behavior.

Previous research has shown that comparisons to the industry are a more consistent predictor of irresponsible behavior than comparisons to one's own performance (e.g., Harris and Bromiley, 2007), especially for firms performing below expectations relative to their industry. However, these results were for publicly held firms whose managers would need to be cognizant of how their relative industry performance was impacting share prices. In our sample of privately held firms, we expect that performing poorly regardless of whether it is relative to historical (own) or social aspirations (industry) would lead to irresponsible behavior. Subsequently, we propose the following:

H1: The further a firm's performance is below its aspirational performance level, the greater its likelihood of an EHS breach.

\subsection{Performance above aspirational levels}

For firms performing above aspirations it seems intuitive to suggest that managers will want to maintain the status-quo and protect the firm's current wealth (Martin et al., 2013). Yet the literature often finds the opposite (e.g., Baucus and Near, 1991; Harris and Bromiley, 2007; Kim et al., 2015), and there is literature on other forms of risk taking that show similar patterns (Martin et al., 2013; Hoskisson et al., 2017). Previous 
research provides support for both the prediction that firms performing above aspirations will be risk averse (Kahneman and Tversky, 1979) and that they will be risk seeking (Greve, 2003). And the explanations as to why they might be risk seeking are sometimes contradictory. The literature provides three basic explanations for how firms performing above aspirations would behave. Each of these finds some support in the literature.

First, these firms are risk averse and wish to protect the status quo. Their goal will be to minimize losses and protect their current wealth (Kahneman and Tversky, 1979; Martin et al., 2013). Therefore, they will frame the choice as being between a certain loss (the cost of compliance) and an uncertain but larger loss (to breach). Firms who frame the choice this way will choose compliance for a very wide range of probabilities of being caught. Hence, even if they had no other options to improve performance, they would still take the certain but smaller loss.

It is intuitive to assume that firms performing above aspirations would perceive the choice in this manner. However, some of the empirical evidence suggests otherwise (e.g., Mishina et al., 2010). The literature offers two main, but somewhat contradictory, explanations for why firms performing above aspirations are risk seeking and not risk averse.

Managerial hubris has been posited to explain why some firms performing above aspirations could be more likely to breach (e.g., Mishina et al., 2010; Tarakci et al., 2018). Hubris would change calculations on the likelihood of outcomes, with hubristic firms believing that they are too smart to get caught and can get away with things others 
cannot (Mishina et al., 2010). When calculating each prospect's likelihood, hubristic firms would reduce the likelihood of getting caught, hence increasing the expected value of breaching.

Hubris can explain the Deepwater Horizon oil spill in the Gulf of Mexico in 2010. At the time of the incident, BP was not struggling to survive. Quite the opposite: in the decade prior to the spill BP had been highly profitable and grown to the second largest company in the oil industry (Lyall, 2010). The spill had multiple causes (Neill and Morris, 2012). However, much of the liability has been placed on BP, whose poor safety culture and lack of emergency planning contributed to both the incident occurring and the amount of damage it caused (Neill and Morris, 2012). BP had other fatal safety incidents prior to the Deepwater Horizon spill. And after a fatal refinery fire in 2005 BP was described as "...very arrogant and proud and in denial... It is possible they were fooled by their success" (Lyall, 2010). Pride and arrogance convincing managers that they can successfully do what others cannot is in line with the hubris explanation.

The third and final explanation offered in the BTF literature is loss aversion (Mishina et al., 2010) and likely decreases in future wealth (Martin et al., 2013). Firms that are performing well, especially those performing far above aspirations, will perceive that their future performance is likely to drop or that they will not meet future improvement goals. Rather than the optimism of the hubristic belief of being able to do what others cannot, such firms are relatively pessimistic about their future. From an external perspective performance may be high, but the firm perceives that future wealth will 
decline. When searching for ways to continuously improve performance, firms will eventually run out of less risky options.

"Consequently, the CEOs and managers of firms experiencing high external expectations are likely to frame the future as a choice between an almost certain loss if they fail to make changes or a chance to stave off that loss if they engage in riskier behaviors..". (Mishina et al., 2010, p. 705)

Compliance is then a certain loss, while breaching is an uncertain loss; hence the choice is made to breach. The loss aversion explanation seems to fit the Volkswagen (VW) emissions case. In the run up to the scandal VW was the second largest carmaker in the world, growing and highly profitable (Topham, 2017). Selling "clean" diesels in the United States (US) was key to reaching their goal of being the largest carmaker in the world by volume (McGee, 2018). However, VW engineers were convinced that emissions regulations in the US were going to be hard if not impossible to satisfy (McGee, 2018). VW would miss their goal if they could not sell more diesel cars in the US, but their initial search for legal solutions was not fruitful. The loss aversion explanation posits that when faced with such a decision, a firm whose performance is high is more likely to take risks (Kahneman, 2011; Mishina et al., 2010), such as installing defeat devices to avoid missing the goal, which is apparently what VW did.

H2: The further a firm's performance is above its aspirational performance level, the greater its likelihood of an EHS breach. 
Figure 1 provides a graphical illustration of the predictions of the direct hypotheses. The $\mathrm{x}$-axis indicates the firm's distance from its aspirational performance level (social and historical), and the y-axis indicates the likelihood of an EHS breach. The steepness of the three slopes $(\mathrm{a}=$ performance below social and historical aspirations, $\mathrm{b}=$ performance above social aspiration, $\mathrm{c}=$ performance above historical aspiration) indicates the hypothesized relationship between the likelihood of an EHS breach and deviations from aspirational performance. Previous literature suggests that the slope for below aspirations (slope a) is steeper than the slopes for above aspirations (e.g., Baum et al., 2005) and that the slope for above social aspirations is steeper than the slope for above historical aspirations (Tarakci et al., 2018). Firms take fewer risks when their performance exceeds their aspirational levels compared to when their performance falls below aspirational levels (Mezias et al., 2002); however they still take more risks than firms who are meeting their aspirational level (Harris and Bromiley, 2007).

[Figure 1 about here]

It is important to note that it is possible that a firm performing above (below) its historical aspiration can also perform below (above) its social aspiration. However, the majority of firms in our sample are performing above both historical and social aspirations or below both historical and social aspirations. We conducted robustness checks for the minority of mixed cases (Tables $\mathrm{H}$ and I). 


\subsection{Slack and performing below aspirations}

Operations managers have multiple paths to performance improvement, and not all operations are equally efficient or effective. Nor are all means of improving operational performance equally risky, and operations managers' willingness to engage in risky options is related to their relative performance and their options. Hence, operations managers in firms performing below aspirations would be more or less likely to breach EHS regulations depending on the availability of other options.

In the operations management literature these options often come in the form of slack (Hendricks et al., 2009; Modi and Mishra, 2011). Slack is excess resources relative to the minimum amount required to produce a given level of output (Nohria and Gulati, 1996). A firm with excess capacity can increase output without investing in new equipment, while a firm whose workers produce less per hour relative to a competitor's workers could become more productive without having to hire or add overtime. However, when plant and equipment are fully utilized, or workers are already highly productive, the system will have little slack, and increasing production will require investing in plant and equipment, hiring new workers, or cutting something else, such as the resources devoted to complying with EHS regulations.

Reducing slack is frequently linked to improved operational performance (e.g., Modi and Mishra, 2011). However, reducing slack has also been linked to some firms increasing the risk of harming their workforce (Wiengarten et al., 2017). Firms performing below aspirations that have slack can improve operational performance without putting the workforce in jeopardy. But as slack decreases, the pressure on 
workers and the system also increases, eventually leading to role overload, and some firms breaching EHS regulations (McLain, 1995; Landsbergis, 2003; Westgaard and Winkel, 2011).

In our context this means that when a firm performs a problemistic search in an operations setting where there is excess slack, they can improve performance by removing slack. However, if there is little slack, they will either need to make investments in new equipment, training and so on or cut resources from elsewhere; in our context, a small but significant percentage of firms may turn to cutting the resources devoted to complying with EHS regulations. We test this supposition by proposing that firms that have slack are less likely to breach EHS regulations when performing below their aspirations.

H3: Additional slack relative to industry averages can attenuate the likelihood of EHS breaches for firms performing below aspirations.

\subsection{Slack and performing above aspirations}

If firms performing above aspirations are more likely to breach, as predicted in $\mathrm{H} 2$, then the effect of slack on the relationship between performance above aspirations and the likelihood of a breach would depend on if this relationship is due to loss aversion or hubris. Hence, competing hypotheses regarding the role of slack when performing above aspirations are presented. Mishina et al. (2010) suggested both hubris and loss aversion to explain their above aspirations results. However, they note they did not have the means to determine which was actually occurring. We posit that slack might help 
to provide theoretical clarity here. Specifically, we posit that if loss aversion is the explanation for some firms breaching when performing above aspirations, then firms would only explore breaching if, after a problemistic search, they concluded they had no other options for improving operational performance. Therefore, if loss aversion explains the above aspirations results, then slack should moderate the aspirational performance breach relationship for these firms.

H4: Additional slack relative to industry averages can attenuate the likelihood of EHS breaches for firms performing above aspirations.

However, hubristic firms would be making a different decision. The hubristic firm believes that they can do what others cannot—in this context breaching without getting caught and hence avoiding the certain costs of compliance. In other words, if hubris explains why increased aspirational performance leads to an increased propensity to breach, then the presence of slack would not influence a firm's decision to be in breach since breaching is framed as a highly likely gain, and they are not looking for other options. Hubristic firms could also remove slack if they had it, but they might simultaneously breach since both could reduce costs and improve operational performance.

H4 (competing): Additional slack relative to industry averages does not attenuate the likelihood of EHS breaches for firms performing above aspirations.

We operationalize slack based on three main sets of resources operations managers have control over: capacity, people, and inventory. Decreases in slack are associated with creating more sales from the same base of resources (Ballou, 2003). 


\section{Method}

To answer our research questions, we compiled secondary data to create a sample of privately held UK manufacturing firms (UK Standard Industrial Classification [SIC] codes 10-33). We tested our model in the manufacturing sector because manufacturing firms are responsible for most EHS breaches. We limited our data to private firms because, while previous research on irresponsible behavior has focused mainly on large publicly held firms (e.g., Harris and Bromiley, 2007), most firms are small and privately held (e.g., Kull et al., 2018).

The data came from three sources. Financial data were obtained from the Financial Analysis Made Easy (FAME) database, the safety breach data came from HSE database of the UK government, ${ }^{2}$ and the environmental breach data were collected from the Enforcement Actions database operated by the Environmental Agency of the UK government. ${ }^{3}$

The EHS breach data were used to create the dependent variable in our models. EHS breaches, unlike accidents that may be caused by worker behaviors or system failures, indicate that the firm broke the law and did not meet society's minimal expectations. Breaches are very rare, but being found in breach is evidence of irresponsible managerial behavior and that senior management places a low strategic priority on protecting workers and the environment. We propose that irresponsible behavior in the guise of a breach is the result of the problemistic search initiated due to performance

\footnotetext{
2 http://www.hse.gov.uk/prosecutions/

${ }^{3}$ https://environment.data.gov.uk/public-register/view/search-enforcement-action
} 
deviations. The breaches occurred between 2008 and 2012. The financial data (FAME) was used for the independent variables, which have a one-year lag to the dependent variable. Thus, the financial data covered 2007 to 2011.

EHS breaches are rare events. In our data the likelihood of a firm having a breach in any given year is only $2.5 \%$. Thus, we reiterate that our subsequent findings are only representative for a small, yet significant, number of managers for whom the problemistic search ends in a breach.

The probability of rare events may be underestimated using panel data and regression analysis (King and Zeng, 2001). Therefore, we followed the previous literature on rare events (e.g., Harris and Bromiley, 2007; Yiu et al., 2014) and created a matched-sample dataset, which is appropriate for studying rare events (O'Connor et al., 2006). This approach resulted in a sample of 374 firms, or 187 pairs, for the analysis. These firms were in 19 of the 23 two-digit manufacturing SIC codes; there were no firms in SIC codes 12, 14, 15, and 26.

The sub-sample of firms with breaches is non-random. Hence, the matching firms were much more typical of the population. Our analysis does not use firms with missing data. There are 12,432 manufacturing firms in the FAME database, but only 2,724 had no missing data from 2007-2011. Given the large number of firms that were discarded for missing data, we conducted independent $t$-tests between the discarded firms and retained firms to examine whether the missing data are random or systematic. The differences between the two groups were non-significant in terms of return on assets 
(ROA) and sales $(p>0.1)$. Using only firms with complete data should not bias our results.

We matched each firm that breached EHS regulations with a control firm identified as having the closest annual sales volume (in the year prior to the breach, $t-1$ ) and in the same industry (two-digit SIC codes) without a breach. The control firm's sales were calipered within a range of $50 \%$ to $200 \%$ of the breach firm's sales at $t-1$ (Barber and Lyon, 1996). The average sales are not significantly different between the breach and control firms (independent $t$-test: $p>0.1$ ), which suggests that they are good matches (Harris and Bromiley, 2007).

Of the 187 firms that breached EHS regulations, 33 breached environmental regulations, and 157 breached safety regulations, with three firms breaching both environmental and safety regulations in the same year. For the firms with breaches, 38 had breaches in multiple years: 34 had breaches in two years, three had breaches in three years, and one had breaches in four years. Each year was treated as an independent event, and control firms were chosen on a year-by-year basis. In other words a firm with multiple breach years could be matched to different control firms in different years.

\subsection{Measures}

The dependent variable "EHS breach" was measured as whether firm $i$ has an environmental or safety breach in year $t$. Firms with one or more breaches in year $t$ were coded as " 1 ," and firms without a breach were coded as " 0 ." Using a binary measure is 
consistent with the previous literature studying other forms of firm malfeasance, such as safety violations (Fan and Zhou, 2018) or financial fraud and misrepresentation (Harris and Bromiley, 2007; Yiu et al., 2014). Only 15 firms in our sample have two breaches in the same year, and there is only one firm with three breaches in the same year. Hence using a binary measure instead of the number of breaches also mitigates the potential bias caused by outliers or the distribution of the number of breaches (Franses and Haldrup, 1994). Each breach record was treated as equal regardless of the type of breach (safety or environmental) or the amount of the fine. This approach is consistent with the previous literature (e.g., Pagell and Gobeli, 2009; Lo et al., 2014; Fan and Zhou, 2018). Although the amount of the fine may vary, the breach itself is the critical event because prosecutions are very rare, and convictions indicate that criminal behavior occurred. Thus, regardless of the size of the fine, the firm has acted irresponsibly and harmed the environment or its workers and reputation. Additionally, individual managers are sometimes held liable for their actions related to the breach.

Unless stated otherwise, all of the independent variables for firm $i$ have a one-year lag to the dependent variable. H1 and H2 hypothesized that the more a firm's performance deviated from its historical and social aspirations, the greater its likelihood of breaching EHS regulations. The aspirational levels serve as reference points for a firm to determine whether it has reached its performance goals (Bromiley and Harris, 2014).

We measure the difference between actual performance and the reference point, for historical aspirations, as ROA at year $t-1$ minus the average ROA in the past two years 
$(t-2$ and $t-3)$ (Harris and Bromiley, 2007). The calculations for historical aspirations are in formulas (1) to (4):

Performance above historical aspirations ${ }_{i t-1}$

$=\mathrm{ROA}_{i t-1}-\left(\mathrm{ROA}_{i t-2}+\mathrm{ROA}_{i t-3}\right) / 2$ if Performance above historical aspirations ${ }_{i t-1}>0$

$=0 \quad$ if Performance is at or below historical aspirations $s_{i t-1}<=0$

Performance below historical aspirations ${ }_{i t-1}$

$=0 \quad$ if Performance is at or above historical aspirations $s_{i-1}>=0$

$=\mathrm{ROA}_{i t-1}-\left(\mathrm{ROA}_{i t-2}+\mathrm{ROA}_{i t-3}\right) / 2$ if Performance below historical aspirations $i t-1<0$

The calculations for social aspirations are as follows (Yiu et al., 2014); the reference point is the average (mean) ROA for the industry (two-digit SIC code):

Performance above social aspirations ${ }_{i t-1}$

$=\mathrm{ROA}_{i t-1}-$ industry average $\mathrm{ROA}_{\mathrm{t}-1}$ if Performance above social aspirations ${ }_{i t-1}>0$

$=0 \quad$ if Performance is at or below social aspirations $i_{i t-1}<=0$

Performance below social aspirations $i t-1$

$=0 \quad$ if Performance is at or above social aspirations $s_{i-1}>=0$

$=\mathrm{ROA}_{i t-1}-$ industry average $\mathrm{ROA}_{\mathrm{t}-1}$ if Performance below social aspirations $s_{i t-1}<0$

A " 0 " indicates that the firm's performance does not fall into this category. For instance a firm coded as "0" for below historical aspirations would have performance that was at or above historical aspirations. Hence, the BTF would not predict that this firm would breach in the below historical aspirations model.

The measurement of relative performance is a spline function in which the variable coefficient can change at a predetermined point (Greene, 2008; Greve, 1998). Historical and social aspirations are operationalized independently: it is assumed that firms 
consider both as salient, but that they need not be perceived identically. These measures provide flexibility and acknowledge the probability that firms may vary their referents (Bromiley and Harris, 2014). This approach has been widely used in previous BTF literature (e.g., Greve, 1998; Baum et al., 2005; Baum and Dahlin, 2007; Bromiley and Harris, 2014; Yiu et al., 2014) and allows for different slopes for performance above and below aspirations (Greve, 1998; Baum et al., 2005), which facilitates comparisons between the varying performance situations (Bromiley and Harris, 2014). Once more it is possible that a firm performing above (below) its historical aspiration can also perform below (above) its social aspiration. Thus, we include Table 1 to provide deeper insight into our sample. We identify that historical and social aspirations are generally consistent in terms of being above or below aspirations in our sample: $64.17 \%$ for breaching firms $(\chi 2=15.12, p<0.01)$ and $60.43 \%$ for non-breaching firms $(\chi 2=7.80$, $\mathrm{p}<0.01)$

[Table 1 about here]

In $\mathrm{H} 3$ and H4, we examine the moderating effects of operational slack in terms of production capacity utilization, labor productivity, and inventory turnover. We operationalize these three moderators as follows. Capacity utilization was calculated as the value of the firm's annual sales divided by plant, property, and equipment (Modi and Mishra, 2011). A firm's labor productivity was calculated as the annual sales divided by the number of employees (Lo et al., 2014). Inventory turnover was calculated as the annual sales divided by the average inventory value (Ballou, 2003). 
These variables were standardized according to the industry mean and standard deviation (two-digit SIC code) in the same year (Hendricks et al., 2009).

We also included a number of control variables to improve the validity and generalizability of our results. We controlled for firm size (number of employees) and firm gross profits by calculating the Berry ratio (gross margin divided by operating expense). We included these controls because firms with more employees and higher gross profits may have more human and financial resources available to operations managers looking to improve performance. Working capital was included to control for a firm's liquidity for the same reason. It was calculated as a company's total current assets minus its total current liabilities scaled by the number of employees (Fazzari and Petersen, 1993). We also included wages per employee and selling, administrative, and general expenses (SG\&A) to control for the firm's willingness to invest in their workers. We control for ownership (the percentage of top managers who are also owners) and compensation (wages paid to the top managers scaled by total compensation) to account for the links between the firm's level of risk and individual managers' level of risk. Having a stake in the firm would link a manager's personal wealth and firm performance, thus the manager would bear a higher risk from organizational decision making (Wiseman and Gomez-Mejia, 1998). However, if decision makers are compensated mainly with money, the link between the firm's level of risk and an individual's level of risk will be weak.

Finally, in a matched-sample design, each matched pair needs to be controlled for due to the fixed effects related to the year of the breach as well as the industry context, 
which includes regulation, macroeconomic conditions, and industry seasonality (O’Connor et al., 2006; Harris and Bromiley, 2007; Yiu et al., 2014). Thus, we also included dummy variables for the matching pairs. We performed natural logarithm transformations on firm size and wages to correct skewed distributions.

\subsection{Endogeneity}

Despite the multiple control variables that are included in the analysis, there may still be endogeneity issues. Endogeneity concerns may arise due to reverse causality. In our model, the independent variables have a time lag to the dependent variables. Therefore, the odds of reverse causality are reduced. However, endogeneity may also arise from the confounding effects of unobserved variable(s); the associations in the regression models may occur because both the independent and dependent variables are related to an unobserved variable (Wooldridge, 2015). For example, a firm with unprofessional management may have poor financial and EHS performance. Even with fixed effects included in the model to mitigate the confounding effects from timeinvariant factors, the risk caused by confounding factors might bias the statistical estimation (Ketokivi and McIntosh, 2017).

We adopted the Heckman selection two-stage analysis to address this concern (Heckman, 1979). In the first stage (the selection model) we determine the factors that predict the probability of observations having a positive or negative relative performance in year $t$-1. Therefore, an aggregated relative performance measure was 
calculated by combining ROA performance relative to historical aspiration plus ROA performance relative to social aspiration (Greve, 2003):

Aggregate aspirational $\mathrm{ROA}_{i t}$

$$
=\left[\mathrm{ROA}_{i t}-\left(\mathrm{ROA}_{\mathrm{it}-1}+\mathrm{ROA}_{\mathrm{it}-2}\right) / 2\right]+\left[\mathrm{ROA}_{\mathrm{it}}-\text { industry average } \mathrm{ROA}_{\mathrm{it}}\right](5)
$$

Formula (5) weighs historical aspiration and social aspiration equally. Observations with the aggregate ROA above aspirations (were positive) were coded as "1," while observations with the aggregate ROA below aspirations (were negative) were coded as "0." This binary variable is regressed on both firm and industry independent variables. To fulfill the exclusion restriction requirement of the Heckman two-stage analysis, at least one independent variable should be an exogenous variable and related to the endogenous variable — in this research, relative performance (Leung and $\mathrm{Yu}, 1996$; Puhani, 2000). Therefore, we followed the previous econometric literature and used industry variables as exogenous independent variables (Reinikka and Svensson, 2006; Fisman and Svensson, 2007; Lin et al., 2011). Specifically, industry munificence (measured as industry sales growth) and industry concentration (measured as Herfindahl-Hirschman Index [HHI]) were included. Industry munificence captures economic conditions, and industry concentration captures the competitiveness of the industry, which relate to the firm's relative performance and are exogenous to the firm. To increase the explanatory power of the selection model, we also include the firm's actual ROA, total assets (natural logarithm transformed), wages per employee (natural logarithm transformed), industry, and year dummy variables. This probit analysis 
generates the inverse Mill's ratio for each observation. The inverse Mill's ratio is the probability density function divided by the cumulative distribution function of the standard normal distribution (Chen et al., 2009). We then included the calculated inverse Mill's ratio in our subsequent models for hypotheses testing to correct for the possibility of endogeneity.

\section{Results}

We conducted probit regression analyses because the dependent variables are binary. A separate conditional logistic regression was conducted as a robustness check (see Appendix B Table B). We used Stata 14.0 to test our hypotheses. The descriptive statistics and correlations are presented in Table 2. The average variance inflation factor (VIF) of the variables is 1.28 . The maximum VIF of random variables is 1.66. Thus, collinearity should not be a serious concern in our analysis.

[Table 2 about here]

Table 3 displays the results of the probit regression analysis used to test $\mathrm{H} 1$ and $\mathrm{H} 2$. Model 1 includes all of the control variables, the inverse Mill's ratio, and the direct effects of the three moderators. The omnibus test shows that the variables create satisfactory controls $\left(\mathrm{Chi}^{2}=97.14, \mathrm{p}<.01\right)$. The coefficient of the inverse Mill's ratio is significant $(9.801, \mathrm{p}<.01)$, which suggests that endogeneity could bias our results if the inverse Mill's ratio was not included.

[Table 3 about here] 
We added performance below historical and social aspirations into Models 2 and 3, respectively, to examine $\mathrm{H} 1$. The coefficient of below historical aspiration is significantly negative $(-9.715, \mathrm{p}<.01)$, and the coefficient of below social aspiration is also significantly negative $(-10.279, \mathrm{p}<.01)$. Thus, the more some companies slip in terms of their performance below their historical and social aspirations, the higher their likelihood of breaching. For a firm with an ROA lower than its average ROA (its historical aspiration) in the previous two years, when holding other variables at zero, a further $0.1 \%$ decrease in ROA increases the likelihood of the firm breaching EHS regulations by $0.972 \%,{ }^{4}$ once more noting that breaches overall are very rare. Similarly, for a firm with an ROA lower than the industry average ROA (its social aspiration), a further $0.1 \%$ decrease in ROA increases the likelihood of the firm breaching EHS regulations by $1.03 \%$. These results support $\mathrm{H} 1$.

To examine H2, we added performance above historical and social aspirations into Models 4 and 5, respectively. The coefficient of ROA above historical aspiration is significantly positive $(6.635, \mathrm{p}<.01)$, and the coefficient of ROA above social aspiration is also significantly positive $(12.765, \mathrm{p}<.01)$. Thus, the more companies are performing above their historical and social aspirations, the higher their likelihood of breaching. For a firm with an ROA higher than their average ROA in the previous two years, when holding other variables at zero, a further $0.1 \%$ increase in ROA increases the likelihood of the firm breaching EHS regulations by $0.664 \%$. Similarly, for a firm with an ROA higher than the industry average ROA, a further $0.1 \%$ increase in ROA

\footnotetext{
${ }^{4}$ Probability $=0.1 \% * 9.715=0.972 \%$
} 
increases the likelihood of the firm breaching EHS regulations by $1.277 \%$. These results support H2. The goodness-of-fit for Models 2, 3, 4, and 5 are significantly improved compared to Model $1(\mathrm{p}<0.01)$.

The results in Table 2 support our direct hypotheses (H1 and $\mathrm{H} 2$ ). These findings are visualized in Figure 2. Similar shapes have been observed in other studies applying the BTF (e.g., Greve, 1998; Baum et al., 2005). There is a significant difference between the slopes for above social and above historical, while the other slopes are not significantly different from each other. The weakest (but still significant effect) is for above historical aspirations, and above social aspirations is the strongest effect. That the effects of deviations from social performance are stronger is in line with the previous literature (e.g., Tarakci et al., 2018) and our initial model in Figure 1. However, the literature suggested the effects would be strongest for below aspirational performance and weakest for above historical aspirations (e.g., Baum et al., 2005).

[Figure 2 about here]

Slack resources are a form of options, hence $\mathrm{H} 3$ predicts that firms performing below their historical or social aspirations that have access to slack resources will, all things being equal, be less likely to breach EHS regulations than firms with the same level of aspirational performance without access to these resources. To test $\mathrm{H} 3$, interaction terms were added to the probit regressions to examine the moderating effects of operational slack on the relationship between EHS breaches and ROA below historical aspiration (Table 4) and social aspiration (Table 5). Figures A, B, C, E, and F in Appendix A illustrate the slopes of the significant moderation effects. 
[Tables 4-5 about here]

The results are mixed providing evidence to support or reject H3. Specifically, inventory slack attenuates the likelihood of a breach for firms performing below historical and social aspirations $(\mathrm{p}<0.01)$. Labor slack attenuates the likelihood of a breach for firms performing below social aspirations $(\mathrm{p}<0.01)$ but not historical aspirations $(p>0.1)$. However, capacity slack amplifies the likelihood of a breach for firms performing below historical and social aspirations.

Hypothesis four was formulated as competing hypotheses to explore the somewhat contradictory explanations offered in the literature for firms breaching when performing above aspiration. To test $\mathrm{H} 4$, interaction terms were added to the probit regressions to examine the moderating effects of operational slack on the relationship between EHS breaches and ROA above historical aspirations (Table 6) and social aspirations (Table 7). Figures D and G in Appendix A illustrate the slopes of the significant moderation effects.

[Tables 6-7 about here]

Five of the six tests show that for firms performing above aspirations, the presence of slack either does not influence the propensity to breach $(p<0.1)$ or even increases it (inventory in the above historical model). The only result that does not fit this pattern is that, for firms performing above historical aspirations, the presence of capacity utilization slack can reduce the propensity to breach $(\mathrm{p}<0.05)$. Hence, loss aversion does not seem to explain why operations managers in firms performing above aspirations would breach EHS regulations. In addition, implicit in hubris is the 
assumption that one is smarter than others, so hubris would be most likely to occur when making social comparisons, and the results are unambiguous for above social aspirations. These results lead us to suggest that the hubris explanation is the best fit for our results. Secondary data cannot confirm that hubris is directing the observed relationships, but the results for above aspirational performance are much more in line with hubris than loss aversion.

The moderation tests for slack require some interpterion and are different depending on a firm's relative performance. Based on these tests (see Table 8 for a summary) we come to three conclusions. First, for firms performing above aspirations, the most likely explanation for breaching is hubris. Second, for firms performing below aspirations, slack matters, but the relationships are complicated. Finally, the overall results suggest that the role of slack in the decision to breach is highly contingent on the type of slack and aspirational performance.

[Table 8 about here]

\subsection{Robustness checks}

We conducted a number of additional tests to examine the validity and boundaries of our results (see Appendix B). The robustness checks suggest that our results are not impacted by testing individual splines as opposed to testing a U-shaped function (Table A), including or excluding firms with more than one breach either in the same or multiple years (Tables B and C), differences between small and large firms (Table D), the type of breach (Table F), the estimation method (Table G), and whether the firm 
has consistent or inconsistent historical and social aspirational performance (Tables $\mathrm{H}$ and I). However, there are differences between firms with a single facility and firms with multiple facilities (Table E). Specifically, firms with a single facility are generally more likely to breach the more performance deviates from aspirational levels. However, for firms with multiple facilities this relationship only holds when performance is above aspirational levels. The robustness checks suggest that our main results are valid while also providing interesting and important additional insights into the role of having multiple facilities.

\section{Discussion and conclusion}

Hypotheses 1 and 2 predicted that in general the further a firm was from its aspirational level of performance, the more likely it would be to breach EHS regulations. These predictions are supported for the small yet significant number of firms that breached. Figure 1 posited that the slope for below aspirational performance would be steeper than the slope for above aspirational performance and that the slope for above social aspirational performance would be steeper than the slope for above historical aspirational performance. The results support the conjecture that social comparisons matter most when performing above aspirations, but the differences between the other slopes are insignificant. These results could be due to the operational focus of the research, exploring private not public firms, the UK context, or some combination. Future research will need to explore these differences to understand what about the context mattered. 
These findings are generally in line with previous research using the BTF at the firm level of analysis to explore risky behavior, specifically in terms of financial decision making (Harris and Bromiley, 2007; Mishina et al., 2010; Tarakci et al., 2018). EHS breaches emanate from the operations function and the findings indicate that when a firm's operations managers are faced with deviations from aspirational performance, they, like other managers, will be more likely to engage in irresponsible behavior as the distance from the aspiration grows. Our first key finding is then to confirm that operations managers behave in a manner that is similar to other managers.

Our research differed not just in operational focus but also in looking only at privately held firms. The strong support for $\mathrm{H} 1$ and $\mathrm{H} 2$ indicates that managers in privately held firms behave in a similar manner when performance deviates from aspirational levels. Our second key finding is then that operations managers in private firms behave in highly similar, but not identical, ways to their counterparts in other functions of public firms. Future research should explore whether the small differences we see are due to the locus of the irresponsible behavior being in the operations or the private nature of the firms.

The robustness checks suggest that our results are valid and reliable. But the exploration of single and multiple location firms leads to our third key conclusion that the structure of the operations, at least in terms of the number of locations, impacts decision making.

The tests of $\mathrm{H} 1$ and $\mathrm{H} 2$ also exposed some interesting results related to the control variables that should be explored in future research. First, the coefficients of firm size 
and administrative expenses are significantly positive $(\mathrm{p}<0.01$, Table 3$)$. Large firms and firms spending more resources on administration may have more complex operations, which could increase the likelihood of accidents and breaches (e.g., Lo et al., 2014). However, these firms could also be more visible and hence more likely to be inspected or investigated. Future research should explore these possibilities. The coefficient of wages per employee is significantly negative $(p<0.05$, Table 3$)$. Wages per employee are indicative of investments in human capital, which have been linked to a decreased tendency to put workers at risk (Pagell et al., 2018). Future research should use more precise measures of investments in the workforce to determine if this conjecture is valid.

While $\mathrm{H} 1$ and $\mathrm{H} 2$ were confirmatory in nature, $\mathrm{H} 3$ and $\mathrm{H} 4$, the hypotheses on slack, were exploratory. The overall results for $\mathrm{H} 3$ and $\mathrm{H} 4$ suggest that the role of slack is complicated and dependent on whether the firm is performing above or below aspirations. For firms performing below aspirations (H3) the presence or absence of slack does seem to matter in the decision to breach, but not necessarily in the predicted manner. Specifically, inventory slack reduces the likelihood of a breach for firms performing below historical and social aspirations. Likewise, labor slack reduces the likelihood of a breach for firms performing below social aspirations; however not historical aspirations. Counterintuitively, capacity slack amplifies the likelihood of a breach for firms performing below historical and social aspirations.

Our fourth key finding is that resources under the control of operations managers can moderate the relationship between performing below aspirations and the likelihood 
to breach EHS regulations, but future research is needed to determine if the patterns observed in this research occur in a wider population, and if so why.

Our fifth key finding is that we find very limited evidence (1/6 tests, Table 8$)$ to support the loss aversion explanation for why firms performing above aspirations might breach EHS regulations. Instead, hubris seems to be the best explanation as to why firms performing well breach. Firms performing above social aspirations are most likely to breach (from $\mathrm{H} 2$ ), and the presence of slack does not change their behavior (Table 7). The results for performance above historical aspirations are similar, but the direct relationship is weakest for above historical aspirations, and the role of slack for these firms is also not as clear cut as for the firms performing above social aspirations (Table 6). Hubris is most likely to occur in social comparisons, which is what we observed. This result directly addresses some of the confusion in the BTF literature, but future research will need to replicate this finding and test it outside the operational realm.

Our sixth key finding is that operations management research needs to explore the role of slack in much more detail. The results for slack are complicated and based on relatively small samples of companies with extreme behavior, so we are careful to offer the following as possible explanations, which need to be explored in future research. While the results for the individual forms of operational slack are messy, they offer some intriguing patterns. Labor productivity slack does not seem to play a role in the decision to breach (or not), but inventory and capacity utilization both seemingly do, although in contradictory ways. Inventory slack reduces the likelihood of a breach 
for firms performing below historical and social aspirations but increases the likelihood of a breach for a firm performing above historical aspirations. Capacity slack has the opposite outcomes.

We posit that when a firm is performing poorly and has excess inventory, it can turn that inventory into sales by either selling it or being able to create finished products without having to buy additional materials. In other words, poorly performing firms can run down inventory and improve performance. However, our conjecture for firms performing above their historical aspirations is that if they have excess inventory relative to their competitors, it is not the right inventory to turn into sales. In other words they are already selling more than their historical average, so if they have inventory it is likely not the right inventory and hence cannot be used. Excess inventory slack for firms performing above historical aspirations may be an indication of previous poor decisions and stranded assets. The money and space tied up in inventory reduces their options and may explain why having inventory increases their likelihood of breaching.

Capacity could work in the opposite manner. Hence, a firm performing above its historical average that still has excess capacity can likely use that capacity to create more products from the same assets. However, firms performing poorly with excess capacity may not have the right capacity. Once more previous poor decisions may mean that money, operators, and/or space are tied up in the wrong capacity, reducing, not increasing, the options available to improve performance. These explanations are offered as our best conjectures. They do not address the possibility that having excess inventory or capacity slack is strategic and are as likely to be wrong as right. But they 
do suggest that future research needs to differentiate between the forms of slack and explore the possibility that slack might actually create constraints not options.

Secondary data are useful for exploring irresponsible behavior given the likelihood that primary data would be either difficult to collect or highly biased. However, secondary data are limited in that they cannot address how or whether firms incorporate probabilities into their calculations of the possible gains or losses from compliance or non-compliance (March and Shapira, 1987). Also, the timing of the actual decision(s) to breach is unknown. Finally, secondary data cannot tease out whether firms breach intentionally. Therefore, future research needs to explore how operations managers think about risk when making decisions about possible irresponsible behavior.

This is an easy suggestion to make, but the reality is that future research will have trouble addressing how operations managers make decisions about irresponsible behavior using primary data. One path for future research could be to build on DuHadway et al. (2018) to explore other risky, but legal, actions for indirect insight into irresponsible behavior. Experimental research, especially scenario-based research might also be able to offer insights into how doing well, especially relative to competitors, influences decision making.

\subsection{Implications for theory}

We know the firms in the sample were caught and convicted of breaching EHS regulations. We also know that in this sample, as in previous studies, the likelihood of risky behavior increased as a firm moved further away from its aspirational 
performance. What the results do not directly address is why firms performing above aspirations act irresponsibly.

We propose that our results do not support the loss aversion explanation for how firms performing above aspirations would frame the choice to breach EHS regulations. Instead the results are most consistent with the suggestion that hubris is the process underpinning the choice to breach when doing well (e.g., Tarakci et al., 2018). We reach this conclusion based on the following. First, in our data, performing better than competitors is the stronger trigger of irresponsible behavior. Hubris is a belief that the firm can do things others cannot—a social comparison. This is reinforced by the results of H4. Specifically, while the role of slack is complex, for the firms performing above social aspirations slack does not moderate the decision to breach. Our results indicate that the small percentage of firms that breach when performing relatively well do so even if they have slack resources. Second, the differences between firms with single and multiple locations also point in this direction. The manager of a single facility in a multiple-location firm can attribute poor performance to others in the firm while attributing success to their own skill (Audia and Brion, 2007; Tarakci et al., 2018). Operations managers in single-location firms would be less likely to have this option, which could explain why at multiple locations firms' poor performance is less likely to trigger a breach. The results do not support loss aversion and suggest that hubris is the likely explanation as to why a small number of firms who perform better than their peers breach. While the data point in this direction, this is presently just testable conjecture. 
Hubris may explain why a small percentage of firms that are doing relatively well decide to breach. However, the findings for performing above aspirations still run counter to the predictions of PT. Both the BTF and PT are well established and have strong empirical support. Yet the research on firms performing above their aspirational level of performance frequently has findings that do not fit into PT or that require strong assumptions to use PT to explain firms' decision making (e.g., Mishina et al., 2010).

We made three simplifying assumptions to use PT. First, as previously mentioned we simplified a mixed gamble into a pure gamble. Second, the BTF is about how a firm makes decisions. The BTF does not predict that there is always a single conscious decision to breach. It is also possible that a series of individual decisions, which might be made by multiple managers, lead to the firm being in breach. PT is formulated for a single decision and decision maker. To simplify the hypotheses development we treated breaching (or not) as a single discrete decision.

Third, to use PT at the firm level means assuming that managers behave the same when making firm and individual decisions. Recent research in supply chain risk management shows that individuals make different decisions for the organization about risk than they would for themselves (DuHadway et al., 2018). The operations manager who delays needed maintenance may do so with the hope of increasing their own bonus. In other words from the manager's perspective the choice is framed as a choice between the status quo of a certain personal gain (of nothing) if they comply and an uncertain but greater personal gain (achieving the bonus) if they delay maintenance and nothing breaks. However, the same decision for the firm could be viewed as a certain loss (the 
cost of maintenance) verses an uncertain but much greater loss when the equipment does break.

These far-from- trivial assumptions, our results, and the similar results of others all suggest that while PT and the BTF share similarities they are aimed at fundamentally different levels of analysis and that what holds for individuals may not hold for organizations (e.g., Bromiley et al., 2001; DuHadway et al., 2018). When studying group- or firm-level decision making, we suggest that the BTF is a better choice.

Further exploring hubris and simultaneously addressing individual and organizational (risky) decision making are the research's specific contributions to the BTF and its relationship with PT. The research also makes a pair of more general theoretical contributions. First, while the BTF has been used in previous operations management research (e.g., Kirchoff et al., 2016), its use is not common. Our results suggest that the BTF should play a more prominent role in explaining operations management decision making and that operational decisions need to be explored in light of both the firm's own historical performance and the performance of the firm's peers. Second, the operations management literature has mainly explored sustainability from the perspective of becoming more sustainable or responsible. Furthermore, much of the focus has been on the relationship between profits and becoming more sustainable, with a general conclusion that it pays to be more sustainable (e.g., Montabon et al., 2016). Our results, along with those of Kirchoff et al. (2016) indicate that sustainable operations theorizing is missing not just irresponsible or unsustainable behavior but that this behavior could be the result of performing above expectations. Future research in 
sustainable operations then needs to consider irresponsible behavior and that even firms whose financial performance is above average might have incentives to behave irresponsibly.

\subsection{Implications for practice and policy}

The results also have multiple implications for managers trying to prevent irresponsible behavior in their operations or supply chain. The BTF and our results suggest that top managers need to be cognizant of the fact that irresponsible behavior could manifest when things are going well and that their top performers, especially in a multi-facility company, may also be the ones most likely to behave irresponsibly.

We also identified that having slack resources does not seem to prevent irresponsible behavior, especially in firms performing well. This is an important finding for top management that is trying to build or maintain a responsible business. Thus, other processes and controls, such as certifications (Lo et al., 2014), need to be considered. Finally, it is important to reiterate that only a small percentage of firms in the population breached. The majority of firms did not, irrespective of their relative performance. Nevertheless, this small percentages of firms is having a detrimental effect on the environment and workers' health and safety.

The results also have implications for policy. Regulators have typically focused their efforts on firms in dirty or dangerous industries. But the present research, along with other recent studies, such as Wiengarten et al. (2017), suggests that enforcement can be much more targeted based on the firm's operational resources and performance. While 
we would expect most regulators to intuitively conclude that poor performers could take risks at the expense of their workers or the environment, the likelihood of top performers also behaving irresponsibly is probably not their conjecture; our results suggest it should be. 


\section{References}

Argote L, Greve H. 2007. A behavioral theory of the firm - 40 years and counting: Introduction and impact. Organization Science 18(3), 337-349.

Audia, P.G., Brion, S. 2007. Reluctant to change: Self-enhancing responses to diverging performance measures. Organizational Behavior and Human Decision Processes 102(2), 255-269.

Ballou, R.H. 2003. Business logistics/supply chain management. London: Pearson Education.

Barber, B.M., Lyon, J.D. 1996. Detecting abnormal operating performance: The empirical power and specification of test statistics. Journal of Financial Economics 41(3), 359-399.

Baucus, M.S., Near, J.P. 1991. Can illegal corporate behaviour be predicted? An event history analysis. Academy of Management Journal 34(1), 9-36.

Baum, J.A.C., Dahlin, K.B. 2007. Aspiration performance and railroads' patterns of learning from train wrecks and crashes. Organization Science 18(3), 368-385.

Baum, J.A.C., Rowley, T.J., Shipilov, A.V., Chuang, Y.T. 2005. Dancing with strangers: Aspiration performance and the search for underwriting syndicate partners. Administrative Science Quarterly 50(4), 536-575.

Birnbaum, M.H. 2006. Evidence against prospect theories in mixed gambles with positive, negative, and mixed consequences. Journal of Economic Psychology 27, 737-761.

Bromiley P. 1991. Testing a causal model of corporate risk taking and performance. Academy of Management Journal 34(1), 37-59.

Bromiley, P., Harris, J.D. 2014. A comparison of alternative measures of organizational aspirations. Strategic Management Journal 35, 338-357.

Bromiley, P., Miller, K.D., Rau, D. 2001. Risk in strategic management research. In Hitt, M.A., Freeman, R.E., Harrison, J.S. (Eds.), The Blackwell handbook of strategic management, 259-288. Malden, MA: Blackwell.

Burgen, S., Phillips, T. 2011. "Zara accused in Brazil sweatshop inquiry.” The Guardian. http://www.theguardian.com/world/2011/aug/18/zara-brazil-sweatshop-accusation

Chen, Y., Ganesan, S., Liu, Y. 2009. Does a firm's product-recall strategy affect its financial value? An examination of strategic alternatives during product-harm crises. Journal of Marketing 73(6), 214-226.

Clinard, M.B., Yeager, P.C., Brissette, J., Petrashek, D., Harries, E. 1979. Illegal corporate behavior. U.S. Department of Justice: National Institute of Law Enforcement and Criminal Justice.

Cyert, R.M., March, J.G. 1963. A behavioral theory of the firm. Englewood Cliffs, NJ: Prentice-Hall.

Desai, V.M. 2016. The behavioral theory of the (governed) firm: Corporate board influences on organizations' responses to performance shortfalls. Academy of Management Journal 59(3), 860-879.

DuHadway, S. , Carnovale, S., Kannan, V. 2018., Organizational communication and individual behavior: Implications for supply chain risk management. Journal of Supply Chain Management (in press). 
Fan, D., Zhou, Y. 2018. Operational safety: The hidden cost of supply-demand mismatch in fashion and textiles related manufacturers. International Journal of Production Economics 198, 70-78.

Fazzari, S.M., Petersen, B.C. 1993. Working capital and fixed investment: New evidence on financing constraints. The RAND Journal of Economics 24(3), 328342.

Fisman, R., Svensson, J. 2007. Are corruption and taxation really harmful to growth? Firm level evidence. Journal of Development Economics 83(1), 63-75.

Franses, P.H., Haldrup, N. 1994. The effects of additive outliers on tests for unit roots and cointegration. Journal of Business \& Economic Statistics 12(4), 471-478.

Greene, W.H. 2008. Econometric analysis. $6^{\text {th }}$ ed. New Jersey: Prentice Hall.

Greve, H.R. 1998. Performance, aspirations, and risky organizational change. Administrative Science Quarterly 43, 58-86.

Greve, H.R. 2003. A behavioral theory of R\&D expenditures and innovations: Evidence from shipbuilding. Academy of Management Journal 46(6), 685-702.

Harris, J., Bromiley, P. 2007. Incentives to cheat: The influence of executive compensation and firm performance on financial misrepresentation. Organization Science 18(3), 350-367.

Haunschild, P.R., Rhee, M. 2004. The role of volition in organizational learning: The case of automotive product recalls. Management Science 50(11), 1545-1560.

Heckman, J.J., 1979. Sample bias as a specification error. Econometrica 47(1), 153162.

Hendricks, K.B., Singhal, V.R., Zhang, R. 2009. The effect of operational slack, diversification, and vertical relatedness on the stock market reaction to supply chain disruptions. Journal of Operations Management 27(3), 233-246.

Hoskisson, R., Chirico, F., Zyung, J.D., Gambeta, E. 2017. Managerial risk taking: A multitheoretical review and future research agenda. Journal of Management 43(1), 137-169.

Huq, F.A., Chowdhury, I.N., Klassen, R.D. 2016. Social management capabilities of multinational buying firms and their emerging market suppliers: An exploratory study of the clothing industry. Journal of Operations Management 46, 19-37.

Jacobs, B.W., Singhal, V.R. 2017. The effect of the Rana Plaza disaster on shareholder wealth of retailers: Implications for sourcing strategies and supply chain governance. Journal of Operations Management 49, 52-66.

Kahneman, D. 2011. Thinking, fast and slow. New York: Farrar, Straus and Giroux.

Kahneman, D., Tversky, A. 1979. Prospect theory: An analysis of decision under risk. Econometrica 47, 263-292.

Ketokivi, M., McIntosh, C.N. 2017. Addressing the endogeneity dilemma in operations management research: Theoretical, empirical, and pragmatic considerations. Journal of Operations Management 52, 1-14.

Kim, J.Y., Finkelstein, S., Haleblian, J. 2015. All aspirations are not created equal: The differential effects of historical and social aspirations on acquisition behavior. Academy of Management Journal 58(5), 1361-1388.

King, G., Zeng, L. 2001. Logistic regression in rare events data. Political Analysis 9(2), 
$137-163$.

Kirchoff, J.F., Omar, A., Fugate, B.S. 2016. A behavioral theory of sustainable supply chain management decision making in non-exemplar firms. Journal of Supply Chain Management 52(1), 41-65.

Klassen, R.D., Whybark, D.C. 1999. The impact of environmental technologies on manufacturing performance. Academy of Management Journal 42(6), 599-615.

Kull, T. J., Kotlar, J., Spring, M. 2018. Small and medium enterprise (SME) research in SCM: The case for single-respondent research designs. Journal of Supply Chain Management (in press).

Landsbergis, P.A. 2003. The changing organization of work and the safety of working people: A commentary. Journal of Occupational and Environmental Medicine 45(1), $61-72$.

Lange, D., Washburn, N.T. 2012. Understanding attributions of corporate social irresponsibility. Academy of Management Review 37(2), 300-326.

Leung, S.F., Yu, S. 1996. On the choice between sample selection and two-part models. Journal of Econometrics 72(1), 197-229.

Lin, C., Lin, P., Song, F.M., Li, C. 2011. Managerial incentives, CEO characteristics and corporate innovation in China's private sector. Journal of Comparative Economics 39(2), 176-190.

Lo, C.K.Y., Pagell, M., Fan, D., Wiengarten, F., Yeung, A.C.L. 2014. OHSAS 18001 certification and operating performance: The role of complexity and coupling. Journal of Operations Management 32(5), 268-280.

Lyall, S. 2010. "In BP's record, a history of boldness and costly blunders." The New York Times. http://www.nytimes.com/2010/07/13/business/energyenvironment/13bprisk.html

March, J., Shapira, Z. 1987. Managerial perspectives on risk and risk taking. Management Science 13(11), 1404-1418.

March, J.G., Simon, H.A. 1958. Organizations. New York, N.Y.: John Wiley \& Sons.

Martin, G.P., Gomez-Mejia, L.R., Wiseman, R.M. 2013. Executive stock options as mixed gambles: Revisiting the behavioral agency model. Academy of Management Journal 56(2), 451-472

McGee, P. 2018. "Former Volkswagen engineer released on $€ 3 \mathrm{~m}$ bail." The Financial Times, June 26, 2018.

McKendall, M.A., Wagner, III, J.A. 1997. Motive, opportunity, choice and corporate illegality. Organization Science 8(6), 624-647.

McLain, D.L. 1995. Responses to health and safety risk in the work environment. Academy of Management Journal 38(6), 1726-1743.

Mezias, S.J., Chen, Y.-R., Murphy, P.R. 2002. Aspiration-level adaptation in an American financial services organization: A field study. Management Science 48(10), 1285-1300.

Mishina, Y., Dykes, B.J., Block, E.S., Pollock, T.G. 2010. Why "good" firms do bad things: The effects of high aspirations, high expectations, and prominence on the incidence of corporate illegality. Academy of Management Journal 53(4), 701-722.

Modi, S.B., Mishra, S. 2011. What drives financial performance-resource efficiency or 
resource slack? Evidence from U.S. based manufacturing firms from 1991 to 2006. Journal of Operations Management 29(3), 254-273.

Montabon, F., Pagell, M. Wu, Z. 2016. Making sustainability sustainable. Journal of Supply Chain Management 52(2), 11-27.

Neill, K.A., Morris, J.C. 2012. A tangled web of principals and agents: Examining the deepwater horizon oil spill through a principal-agent lens. Politics \& Policy 40(4), 629-656.

Nohria, N., Gulati, R. 1996. Is slack good or bad for innovation? Academy of Management Journal 39, 1245-1264.

O'Connor, J.P., Priem, R.L., Coombs, J.E., Gilley, K.M. 2006. Do CEO stock options prevent or promote fraudulent financial reporting? Academy of Management Journal 49(3), 483-500.

Pagell, M., Gobeli, D. 2009. How plant managers' experiences and attitudes toward sustainability relate to operational performance. Production and Operations Management 18(3), 278-299.

Pagell, M., Shevchenko, A. 2014. Why research in sustainable supply chain management should have no future. Journal of Supply Chain Management 50(7), 44-55.

Pagell, M., Wiengarten, F., Fan, D., Humphreys, P., Lo, C.K. (2018). Managerial time horizons and the decision to put operational workers at risk: The role of debt. Decision Sciences (in press).

Puhani, P. 2000. The Heckman correction for sample selection and its critique. Journal of Economic Surveys 14(1), 53-68.

Reinikka, R., Svensson, J. 2006. Using micro-surveys to measure and explain corruption. World Development 34(2), 359-370.

Rose, N.L. 1993. Profitability and product quality: Economic determinants of airline safety performance. Journal of Political Economics 98, 944-964.

Shimizu, L. 2007. Prospect theory, behavioral theory, and the threat-rigidity thesis: Combinative effects on organizational decisions to divest formerly acquired units. Academy of Management Journal 50(6), 1495-1514.

Tarakci, M., Ates, N.Y., Floyd, S.W., Ahn, Y., Wooldridge, B. 2018. Performance feedback and middle managers' divergent strategic behavior: The roles of social comparisons and organizational identification. Strategic Management Journal 39, $1139-1162$.

Topham, G. 2017. "VW becomes world's No1 carmaker despite diesel emissions scandal." The Guardian. https://www.theguardian.com/business/2017/jan/30/vwdiesel-emissions-scandal-volkswagen-audi-porsche-skoda-toyota

Tversky, A., Kahneman, D. 1992. Advances in prospect theory: Cumulative representation of uncertainty. Journal of Risk and Uncertainty 5(4), 297-323.

Westgaard, R.H., Winkel, J. 2011. Occupational musculoskeletal and mental health: Significance of rationalization and opportunities to create sustainable production systems - A systematic review. Applied Ergonomics 42(2), 261-296.

Wiengarten, F., Fan, D., Lo, C.K.Y., Pagell, M. 2017. The differing impacts of operational slack on occupational safety in varying market conditions. Journal of 
Operations Management 52, 30-45.

Wilhelm, M.M., Blome, C., Bhakoo, V., Paulraj, A. 2016. Sustainability in multi-tier supply chains: Understanding the double agency role of the first-tier supplier. Journal of Operations Management 41, 42-60.

Wiseman, R.M., Gomez-Mejia, L.R. 1998. A behavioral agency model of managerial risk taking. Academy of Management Review 23(1), 133-153.

Wooldridge, J. M. 2015. Introductory econometrics: A modern approach. Boston: Cengage Learning.

Yiu, D.W., Xu, Y., Wan, W.P. 2014. The deterrence effects of vicarious punishments on corporate financial fraud. Organization Science 25(5), 1549-1571. 


\section{Appendix A}

Figures A to $G$ illustrate the slopes of the significant moderating effects of slack. The graphs show the change in relation to the aspirational level of ROA and the likelihood of an EHS breach based on having a mean score of the moderator (standardized according to industry), a high score of the moderator (one standard deviation above the mean), and a low score of the moderator (one standard deviation below the mean). The $\mathrm{x}$-axis is the level of aspirational ROA from $-0.5 \%$ to 0 (for ROA below aspirational performance) and from 0 to $0.5 \%$ (for ROA above aspirational performance). The $y$-axis is the probability of an EHS breach, where $0 \%$ is set as the probability of a breach occurring when the ROA is exactly at the aspiration level.

Figures A and B illustrate the attenuating effects of inventory slack for firms with an ROA below historical and social aspirations. Moving from the mean to one standard deviation below the mean of inventory turnover (an increase in inventory slack), the slope of ROA below historical (social) aspiration changes $-134.06 \%(-34.34 \%)$. Figure C illustrates the attenuating effect of labor slack for firms with an ROA below social aspirations. Moving from the mean to one standard deviation below the mean of labor productivity (an increase in labor slack), the slope of ROA below social aspiration changes $-24.20 \%$. Figure D illustrates the attenuating effects of production capacity slack for firms with an ROA above historical aspirations. Moving from the mean to one standard deviation below the mean of utilization (an increase in capacity slack), the slope of ROA above historical aspiration changes $-141.75 \%$.

Figures E through $\mathrm{G}$, however, illustrate that increases in slack could also have amplification effects. Figures $\mathrm{E}$ and $\mathrm{F}$ illustrate that decreasing capacity utilization (increasing slack) amplifies the negative effect of ROA below historical and social 
aspirations. Moving from the mean to one standard deviation below the mean of capacity utilization, the slope of ROA below historical (social) aspirations changes $63.94 \%(9.65 \%)$. Figure $\mathrm{G}$ illustrates that decreasing inventory turnover (increasing slack) amplifies the negative effect of ROA above historical aspiration. Moving from the mean to one standard deviation below the mean of inventory turnover, the slope of ROA above historical aspiration changes $305.86 \%$

\section{Appendix B}

We conducted a number of additional tests to examine the validity and boundaries of our results. The primary analysis used a spline function methodology to assess the different slopes of relative performance below and above aspirations (Greve, 1998). The V-shapes (as illustrated in Figure 2) that we found indicate that the likelihood of having a breach increases as performance deviates (both above and below) from aspirations. As a robustness check, we explored whether a U-shape can also be used to describe these relationships. We entered aspirational performance (historical and social) and their squared terms into Model 1 in Table 2. The results are shown in Appendix B Table A. The squared terms for both historical and social aspirational performance are significantly positive $(\mathrm{p}<.01)$. The results are also plotted in Appendix B Figures A and B. This test suggests a U-shape can also describe the relationship between relative performance and breaching EHS regulations. However this approach hides some of the nuance of the differing slopes for above and below aspirational performance.

The sample includes firms with multiple breaches in the same year or across multiple years. These firms may have been specifically targeted by regulators, which would increase their likelihood of being caught if they did breach. On the other hand these 
firms may also learn from past breaches, reducing the odds of future beaches (Haunschild and Rhee, 2004). To explore these possibilities and increase the confidence in our main results, we conducted three additional analyses. First, we added the additional control variable of breach history (measured as number of breaches before year $t$ ) to the analysis. This additional control did not change our results. Second, we eliminated the firms with multiple breaches in the same year and re-ran the models. The results (shown in Appendix B Table B) remain consistent with the results in Table 2. This analysis indicates that our main results were not biased by the firms with multiple breaches in the same year. Third, we eliminated firms with multiple breaches in a single or multiple years and re-ran the models. The results (shown in Appendix B Table C) are also consistent with the results in Table 2. Thus, we conclude that our main results were not biased by firms that had breaches in multiple years.

In our matching process, we controlled for firm size and confirmed that the difference between sample and control firms was non-significant. However, it might still be possible that our results are dependent on the variation in firm size in the sample. Thus, we conducted an additional analysis where firm size is included as a moderator (shown in Appendix B Table D). The coefficients for relative performance $\times$ firm size are not significant $(\mathrm{p}>.1)$ in Models 1,3 , and 4 and negative and marginally significant $(\mathrm{p}<.1)$ in Model 2. Thus, the results are generally consistent for large and small firms.

We also explored whether the effect of relative performance varies between firms with single and multiple facilities. We repeated the analysis for these two subsamples separately and present the results in Appendix B Table E. Model 1 includes the sample for firms with a single facility. The coefficients of performance below both historical and social aspirations remain significantly negative $(\mathrm{p}<.01)$. In addition, the coefficient of performance above social aspiration is significantly positive $(p<.01)$, 
while above historical aspiration is non-significant $(p>.1)$. Model 2 includes the sample for firms with multiple facilities. The coefficients of performance below historical and social aspirations are non-significant $(\mathrm{p}>.1)$. The coefficients of performance above historical and social aspirations are positive and significant $(\mathrm{p}<$ .01). These results suggest differences in operational managers' decision making between firms with single and multiple facilities. Firms with a single facility are generally more likely to breach the more performance deviates from aspirational levels. However, for firms with multiple facilities, responding with a breach only occurs when performance is above aspirational levels. These analyses provide interesting and important additional insights to the main results.

In our primary analysis, environmental and safety breaches were aggregated as one dependent variable. However, the effects of relative financial performance on the likelihood of environmental and safety breaches may differ. Thus, we disaggregated the breaches into environmental and safety breaches. The dependent variable of EHS breaches was replaced by the disaggregated variables environmental and safety breaches. The results are displayed in Appendix B Table F. The effect sizes and directions of the results in both models are largely analogous to our primary results (Table 2, aggregated DV), providing additional support for our initial results. We do note that the coefficients of ROA below historical and social aspirations are nonsignificant in the environmental breach model while significant in the safety breach model, which is likely due to the small number of environmental breaches. We are cautious in coming to any conclusions on environmental breaches given the small numbers, but future research could explore this further.

We used probit regression to examine our hypotheses because the inverse Mill's ratio was included in the model (Greene, 2008). We also reexamined the analysis in 
Table 3 by conducting a conditional logistic regression (Yiu et al., 2014). These results are displayed in Appendix B Table G. The results are largely identical to the results in Table 3. Thus, our results are robust across different estimation methods.

Finally, historical and social aspirations were operationalized independently on the assumption that firms consider both salient but that they need not be perceived identically. Additionally, in about one-third of the firms, historical and social aspirations were inconsistent, with one above aspirations and the other below. Therefore, we separated the matched pairs into two groups - one where the firms have consistent historical and social aspirational performance and a second where they have inconsistent aspirational performance. We re-ran the analyses for $\mathrm{H} 1$ and $\mathrm{H} 2$ for these two groups and present the results in the Appendix B Tables H and I. Table H presents the results for the firms with consistent historical and social aspirational performance, while Table I is for firms with inconsistent aspirational performance. The coefficients of ROA below historical and social aspirations are significantly negative $(p<0.01)$, and ROA above historical and social aspirations are significantly positive in both tables. These results support the assumption that historical and social comparisons are assessed independently and are consistent with the primary analysis. 
Table 1: Sample distribution based on performance

\begin{tabular}{|c|c|c|c|}
\hline \multicolumn{4}{|c|}{ Sample firms with breaches } \\
\hline & & \multicolumn{2}{|c|}{ Performance vs. Historical aspiration } \\
\hline & & Above & Below \\
\hline \multirow{2}{*}{$\begin{array}{l}\text { Performance vs. } \\
\text { Social aspiration }\end{array}$} & Above & 65 & 38 \\
\hline & Below & 29 & 55 \\
\hline \multicolumn{4}{|c|}{ Control firms without breaches } \\
\hline & & \multicolumn{2}{|c|}{ Performance vs. Historical aspiration } \\
\hline & & Above & Below \\
\hline \multirow{2}{*}{$\begin{array}{l}\text { Performance vs. } \\
\text { Social aspiration }\end{array}$} & Above & 65 & 41 \\
\hline & Below & 33 & 48 \\
\hline
\end{tabular}


Table 2: Descriptive statistics and correlations; $N=374$

\begin{tabular}{|r|l|c|c|c|c|c|c|c|c|c|c|c}
\hline & Mean & $\begin{array}{c}\text { Std. } \\
\text { Deviation }\end{array}$ & $\mathbf{1}$ & $\mathbf{2}$ & $\mathbf{3}$ & $\mathbf{4}$ & $\mathbf{5}$ & $\mathbf{6}$ & $\mathbf{7}$ & $\mathbf{8}$ & $\mathbf{9}$ \\
\hline $\mathbf{1}$ & EHS Breach & 0.500 & 0.501 & & & & & & & & \\
\hline $\mathbf{2}$ & ROA below historical aspiration & -0.026 & 0.046 & -0.09 & & & & & & & \\
\hline $\mathbf{3}$ & ROA above historical aspiration & 0.030 & 0.052 & 0.01 & 0.31 & & & & & & & \\
\hline $\mathbf{4}$ & ROA below social aspiration & -0.146 & 0.571 & 0.00 & 0.05 & 0.06 & & & & & & \\
\hline $\mathbf{5}$ & ROA above social aspiration & 0.105 & 0.365 & 0.00 & 0.06 & 0.09 & 0.01 & & & & & \\
\hline $\mathbf{6}$ & Working capital (standardized) & 0.049 & 0.927 & -0.07 & 0.01 & -0.01 & 0.04 & -0.01 & & & & \\
\hline & Production capacity & -0.007 & 0.691 & -0.02 & -0.01 & 0.01 & 0.02 & 0.04 & -0.02 & & & \\
\hline $\mathbf{7}$ & utilization(standardized) & Inventory turnover (standardized) & -0.108 & 0.613 & -0.07 & 0.04 & -0.03 & 0.02 & -0.03 & -0.02 & 0.10 & \\
\hline $\mathbf{9}$ & Labor productivity (standardized) & 0.075 & 0.550 & -0.02 & -0.06 & 0.05 & 0.04 & -0.03 & 0.18 & 0.09 & 0.01 & \\
\hline $\mathbf{1 0}$ & Berry ratio & 1.431 & 0.866 & 0.01 & 0.08 & 0.06 & 0.02 & -0.01 & 0.13 & 0.17 & 0.01 & 0.42 \\
\hline $\mathbf{1 1}$ & Wages per employee (log) & 3.267 & 0.268 & -0.10 & -0.02 & -0.03 & 0.15 & 0.08 & 0.37 & 0.11 & 0.25 & 0.18 \\
\hline $\mathbf{1 2}$ & Firm size (log) & 5.556 & 1.227 & 0.14 & 0.07 & -0.02 & -0.05 & -0.06 & -0.23 & -0.02 & -0.02 & -0.03 \\
\hline $\mathbf{1 3}$ & Administrative expenses & 35.063 & 31.893 & -0.01 & -0.11 & 0.02 & 0.06 & 0.02 & 0.39 & 0.09 & 0.25 & 0.18 \\
\hline $\mathbf{1 4}$ & Ownership & 0.091 & 0.224 & -0.07 & 0.04 & -0.03 & 0.04 & 0.00 & -0.05 & 0.00 & -0.03 & -0.04 \\
\hline $\mathbf{1 5}$ & Compensation & 0.908 & 0.080 & 0.01 & -0.03 & 0.05 & 0.00 & -0.04 & 0.03 & 0.04 & 0.03 & 0.03 \\
\hline $\mathbf{1 6}$ & Inversed Mill's ratio & 0.193 & 0.136 & 0.04 & 0.06 & 0.00 & -0.07 & 0.32 & 0.10 & 0.03 & 0.03 & 0.15 \\
\hline
\end{tabular}




\begin{tabular}{|c|c|c|c|c|c|c|c|c|c|c|}
\hline \multirow{3}{*}{$\begin{array}{l}\mathrm{N}=374 \\
\text { Independent variables }\end{array}$} & \multicolumn{10}{|c|}{ Dependent variable: breach at year $t(1=$ yes; $0=$} \\
\hline & \multicolumn{3}{|c|}{ Model 1} & \multicolumn{3}{|c|}{ Model 2} & \multicolumn{3}{|c|}{ Model 3} & \multirow[b]{2}{*}{ Coef } \\
\hline & Coef. & S.E. & $\mathrm{p}$ & Coef. & S.E. & $\mathrm{p}$ & Coef. & S.E. & $\mathrm{p}$ & \\
\hline Below historical aspiration & & & & -9.715 & 2.818 & 0.001 & & & & \\
\hline Below social aspiration & & & & & & & -10.279 & 3.187 & 0.001 & \\
\hline Above historical aspiration & & & & & & & & & & 6.635 \\
\hline \multicolumn{11}{|l|}{ Above social aspiration } \\
\hline Working capital & 0.194 & 0.150 & 0.196 & 0.218 & 0.152 & 0.152 & 0.228 & 0.143 & 0.111 & 0.256 \\
\hline Production capacity utilization & 0.217 & 0.183 & 0.236 & 0.337 & 0.160 & 0.036 & 0.272 & 0.158 & 0.085 & 0.212 \\
\hline Inventory turnover & -0.166 & 0.190 & 0.384 & -0.260 & 0.326 & 0.425 & -0.176 & 0.271 & 0.516 & -0.121 \\
\hline Labor productivity & -0.263 & 0.241 & 0.275 & -0.439 & 0.244 & 0.072 & -0.229 & 0.228 & 0.315 & -0.361 \\
\hline Firm size & 1.522 & 0.197 & 0.000 & 1.739 & 0.252 & 0.000 & 1.487 & 0.238 & 0.000 & 1.597 \\
\hline Berry ratio & 0.170 & 0.152 & 0.264 & 0.014 & 0.198 & 0.945 & 0.250 & 0.158 & 0.114 & 0.103 \\
\hline Wages per employee & -1.422 & 0.540 & 0.008 & -1.176 & 0.560 & 0.036 & -1.434 & 0.554 & 0.010 & -1.293 \\
\hline Administrative expenses & 0.016 & 0.004 & 0.000 & 0.014 & 0.005 & 0.003 & 0.014 & 0.005 & 0.006 & 0.014 \\
\hline Ownership & -0.386 & 0.528 & 0.464 & -0.147 & 0.526 & 0.780 & -0.190 & 0.507 & 0.707 & -0.329 \\
\hline Compensation & 1.575 & 1.448 & 0.277 & 0.347 & 1.302 & 0.790 & 1.085 & 1.269 & 0.393 & 1.526 \\
\hline Inversed Mill's ratio & 9.801 & 2.581 & 0.000 & 18.011 & 3.247 & 0.000 & 12.167 & 2.633 & 0.000 & 13.619 \\
\hline Pair dummies & Included & & & Included & & & Included & & & Include \\
\hline $\mathrm{Chi}^{2}$ & 97.14 & & & 120.12 & & & 109.66 & & & 106.31 \\
\hline $\mathrm{R}^{2}$ & $18.93 \%$ & & & $23.17 \%$ & & & $21.15 \%$ & & & $20.50^{\circ}$ \\
\hline Incremental $\mathrm{Chi}^{2}$ & & & & 0.000 & & & 0.000 & & & 0.002 \\
\hline
\end{tabular}




\begin{tabular}{|l|c|c|c|}
\hline Table 4: Moderating effects for ROA below historical aspiration & \multicolumn{3}{l|}{} \\
\hline $\mathrm{N}=374$ & Coef. & S.E. & $\mathrm{p}$ \\
\hline Below historical aspiration & -17.132 & 3.990 & 0.000 \\
\hline Below historical aspiration $\times$ Production capacity utilization & 15.852 & 6.019 & 0.008 \\
\hline Below historical aspiration $\times$ Inventory turnover & -37.465 & 13.188 & 0.005 \\
\hline Below historical aspiration $\times$ Labor productivity & 16.474 & 10.211 & 0.107 \\
\hline Working capital & 0.237 & 0.148 & 0.108 \\
\hline Production capacity utilization & 0.594 & 0.182 & 0.001 \\
\hline Inventory turnover & -0.692 & 0.393 & 0.078 \\
\hline Labor productivity & -0.004 & 0.384 & 0.992 \\
\hline Firm size & 1.772 & 0.219 & 0.000 \\
\hline Berry ratio & -0.141 & 0.232 & 0.544 \\
\hline Wages per employee & -1.433 & 0.593 & 0.016 \\
\hline Administrative expenses & 0.013 & 0.005 & 0.004 \\
\hline Ownership & -0.103 & 0.546 & 0.850 \\
\hline Compensation & 1.288 & 1.656 & 0.437 \\
\hline Inversed Mill's ratio & 18.722 & 3.495 & 0.000 \\
\hline $\mathrm{R}^{2}$ & $27.39 \%$ & & \\
\hline
\end{tabular}

\begin{tabular}{|l|c|c|c|}
\hline Table 5: Moderating effects for ROA below social aspiration & Coef. & S.E. & $\mathrm{p}$ \\
\hline $\mathrm{N}=374$ & -15.891 & 3.645 & 0.000 \\
\hline Below social aspiration & 2.220 & 0.567 & 0.000 \\
\hline Below social aspiration $\times$ Production capacity utilization & -8.903 & 2.711 & 0.001 \\
\hline Below social aspiration $\times$ Inventory turnover & -6.991 & 1.931 & 0.000 \\
\hline Below social aspiration $\times$ Labor productivity & 0.281 & 0.165 & 0.088 \\
\hline Working capital & 0.266 & 0.173 & 0.126 \\
\hline Production capacity utilization & -0.342 & 0.178 & 0.055 \\
\hline Inventory turnover & -0.261 & 0.260 & 0.314 \\
\hline Labor productivity & 1.443 & 0.210 & 0.000 \\
\hline Firm size (Employee) & 0.353 & 0.177 & 0.046 \\
\hline Berry ratio & -1.644 & 0.559 & 0.003 \\
\hline Wages per employee & 0.013 & 0.004 & 0.003 \\
\hline Administrative expenses & -0.386 & 0.541 & 0.476 \\
\hline Ownership & 1.047 & 1.520 & 0.491 \\
\hline Compensation & 11.712 & 2.697 & 0.000 \\
\hline Inversed Mill's ratio & $22.90 \%$ & & \\
\hline $\mathrm{R}^{2}$ & & \\
\hline
\end{tabular}




\begin{tabular}{|l|c|c|c|}
\hline Table 6: Moderating effects for ROA above historical aspiration & \multicolumn{5}{l|}{} \\
\hline $\mathrm{N}=374$ & Coef. & S.E. & $\mathrm{p}$ \\
\hline Above historical aspiration & 3.931 & 2.691 & 0.144 \\
\hline Above historical aspiration $\times$ Production capacity utilization & 8.049 & 3.347 & 0.016 \\
\hline Above historical aspiration $\times$ Inventory turnover & -19.615 & 6.968 & 0.005 \\
\hline Above historical aspiration $\times$ Labor productivity & -0.684 & 4.112 & 0.868 \\
\hline Working capital & 0.262 & 0.159 & 0.099 \\
\hline Production capacity utilization & -0.281 & 0.261 & 0.283 \\
\hline Inventory turnover & 0.200 & 0.135 & 0.139 \\
\hline Labor productivity & -0.314 & 0.327 & 0.338 \\
\hline Firm size (Employee) & 1.618 & 0.215 & 0.000 \\
\hline Berry ratio & 0.029 & 0.166 & 0.863 \\
\hline Wages per employee & -1.393 & 0.581 & 0.016 \\
\hline Administrative expenses & 0.014 & 0.004 & 0.001 \\
\hline Ownership & -0.414 & 0.535 & 0.439 \\
\hline Compensation & 1.762 & 1.530 & 0.249 \\
\hline Inversed Mill's ratio & 14.870 & 3.342 & 0.000 \\
\hline $\mathrm{R}^{2}$ & $24.28 \%$ & & \\
\hline
\end{tabular}

\begin{tabular}{|l|c|c|c|}
\hline Table 7: Moderating effects for ROA above social aspiration & \multicolumn{3}{l|}{} \\
\hline $\mathrm{N}=374$ & Coef. & S.E. & $\mathrm{p}$ \\
\hline Above social aspiration & 13.014 & 2.675 & 0.000 \\
\hline Above social aspiration $\times$ Production capacity utilization & -6.075 & 5.681 & 0.285 \\
\hline Above social aspiration $\times$ Inventory turnover & -2.536 & 3.084 & 0.411 \\
\hline Above social aspiration $\times$ Labor productivity & -0.143 & 1.838 & 0.938 \\
\hline Working capital & 0.286 & 0.158 & 0.070 \\
\hline Production capacity utilization & 0.181 & 0.197 & 0.360 \\
\hline Inventory turnover & -0.078 & 0.324 & 0.810 \\
\hline Labor productivity & -0.280 & 0.305 & 0.358 \\
\hline Firm size (Employee) & -0.114 & 0.215 & 0.594 \\
\hline Berry ratio & -1.543 & 0.569 & 0.007 \\
\hline Wages per employee & 1.646 & 0.221 & 0.000 \\
\hline Administrative expenses & 0.017 & 0.004 & 0.000 \\
\hline Ownership & -0.519 & 0.578 & 0.369 \\
\hline Compensation & 1.506 & 1.503 & 0.316 \\
\hline Inversed Mill's ratio & 6.497 & 2.623 & 0.013 \\
\hline $\mathrm{R}^{2}$ & $26.01 \%$ & & \\
\hline
\end{tabular}




\begin{tabular}{|c|c|c|c|}
\hline & \multicolumn{2}{|c|}{ Hypothesis 3 -Below aspirational performance } & Hypotheses $4-\mathrm{Al}$ \\
\hline & Below Historical (Table 4) & Below Social (Table 5) & Above Historical (Tal \\
\hline ROA $\times$ Inventory & $\begin{array}{l}\text { More slack reduces the } \\
\text { likelihood of a breach } \\
\text { Supports H3 }\end{array}$ & $\begin{array}{l}\text { More slack reduces the } \\
\text { likelihood of a breach } \\
\text { Supports H3 }\end{array}$ & $\begin{array}{l}\text { More slack increases } t \\
\text { likelihood of a breach } \\
\text { Supports Hubris }\end{array}$ \\
\hline $\begin{array}{l}\text { ROA } \times \text { Labor } \\
\text { productivity }\end{array}$ & Not significant & $\begin{array}{l}\text { More slack reduces the } \\
\text { likelihood of a breach } \\
\text { Supports H3 }\end{array}$ & $\begin{array}{l}\text { Not significant } \\
\text { Supports Hubris }\end{array}$ \\
\hline $\begin{array}{l}\text { ROA } \times \text { Capacity } \\
\text { utilization }\end{array}$ & $\begin{array}{l}\text { More slack increases the } \\
\text { likelihood of a breach } \\
\text { Opposite of H3 }\end{array}$ & $\begin{array}{l}\text { More slack increases } \\
\text { the likelihood of a } \\
\text { breach } \\
\text { Opposite of H3 }\end{array}$ & $\begin{array}{l}\text { More slack reduces the } \\
\text { likelihood of a breach } \\
\text { Supports Loss aversior }\end{array}$ \\
\hline
\end{tabular}




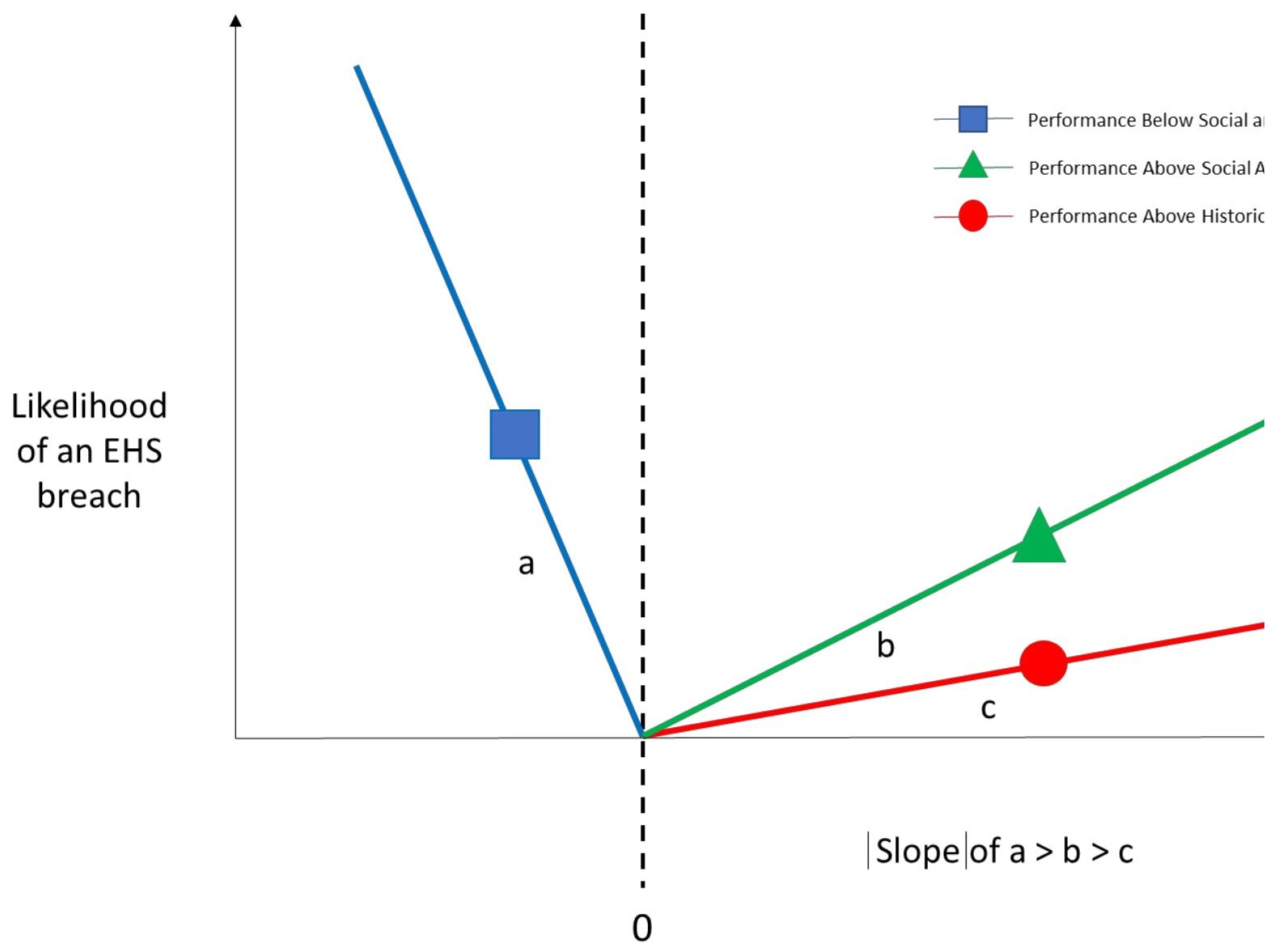

Distance from aspiration

Figure 1: Theoretical model 


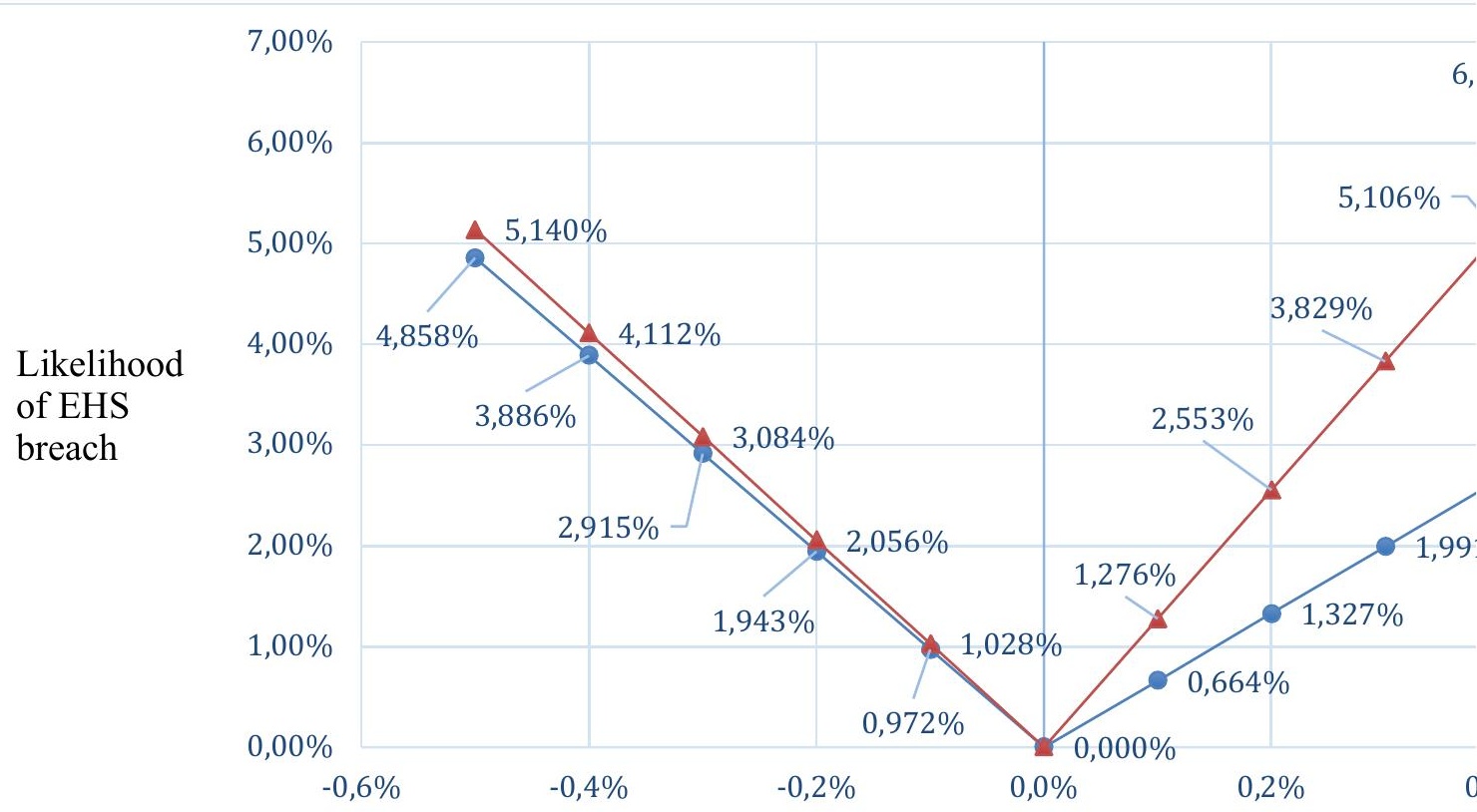

Distance between actual ROA and aspirations

- Distance between actual ROA and historical aspiration $\quad-$ Distance between actual ROA and s

Figure 2: Relationship between ROA (current performance) and aspirations and the likelihood of EHS breac ROA is at the aspiration levels is benchmarked at zero.) 
Appendix A

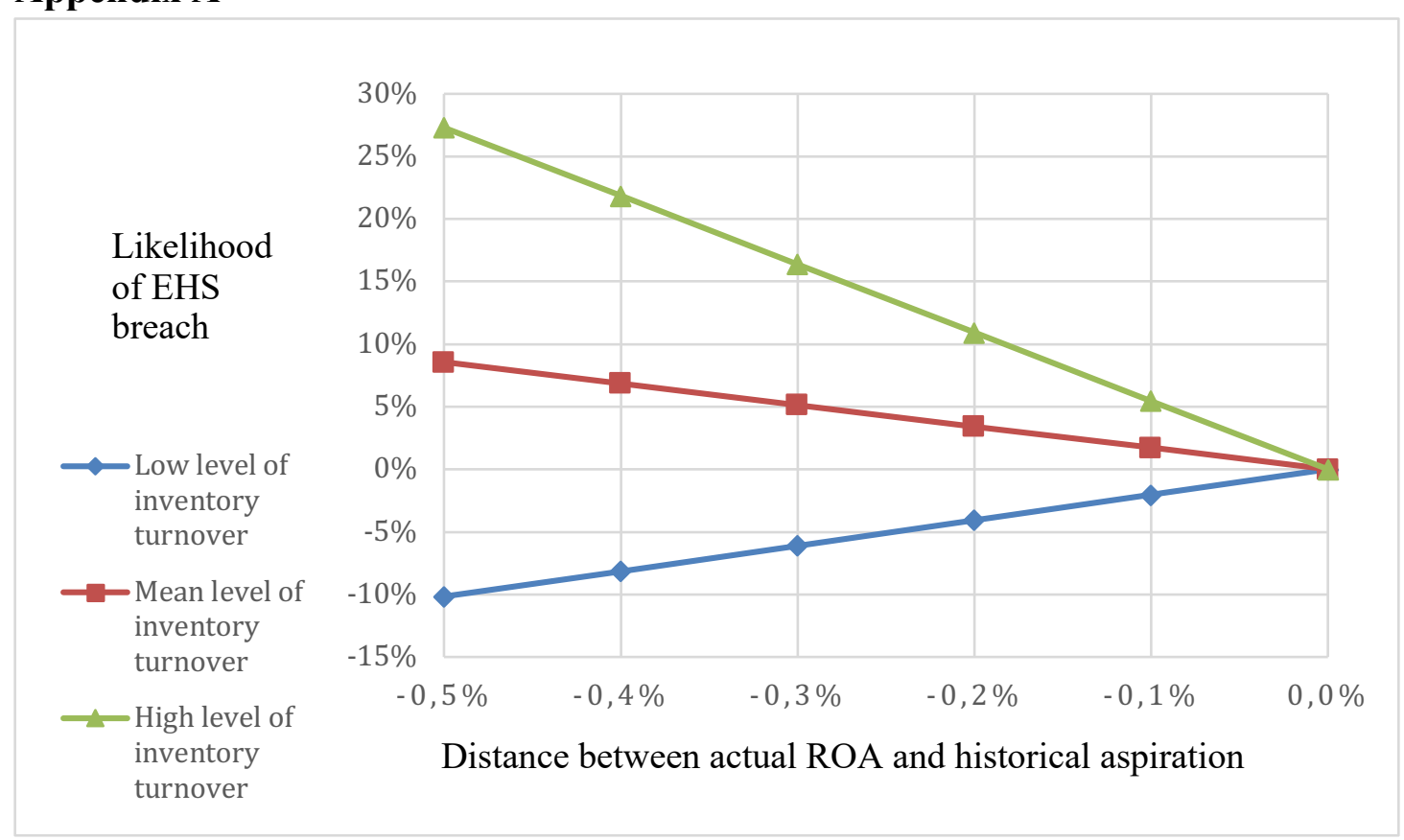

Figure A: Moderating effect of inventory turnover on the relationship between ROA (current performance) below historical aspiration and the likelihood of EHS breach. (The likelihood of a breach when ROA is at the historical aspiration level is benchmarked at zero.)

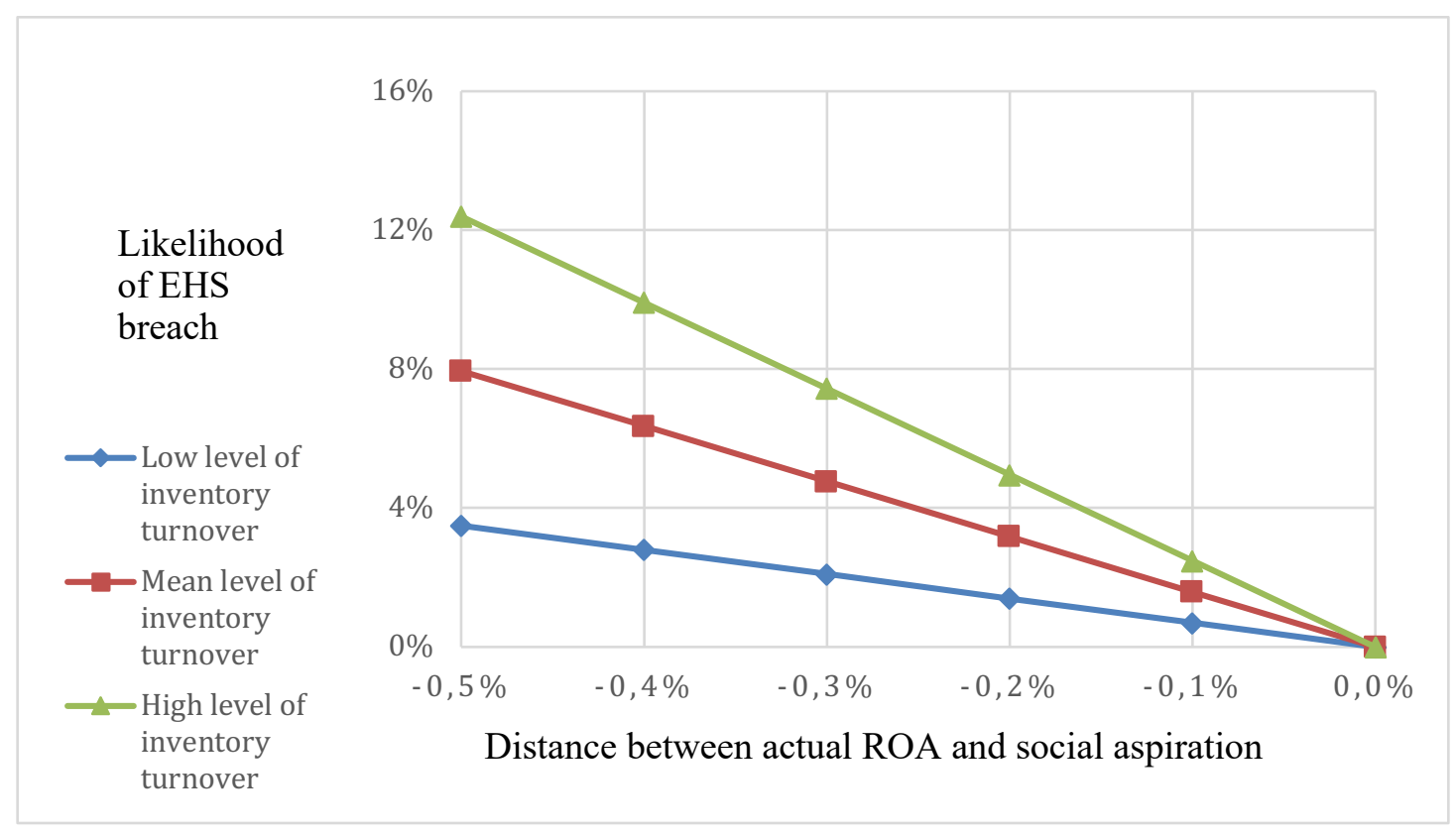

Figure B: Moderating effect of inventory turnover on the relationship between ROA (current performance) below social aspiration and the likelihood of EHS breach. (The likelihood of a breach when ROA is at the historical aspiration level is benchmarked at zero.) 


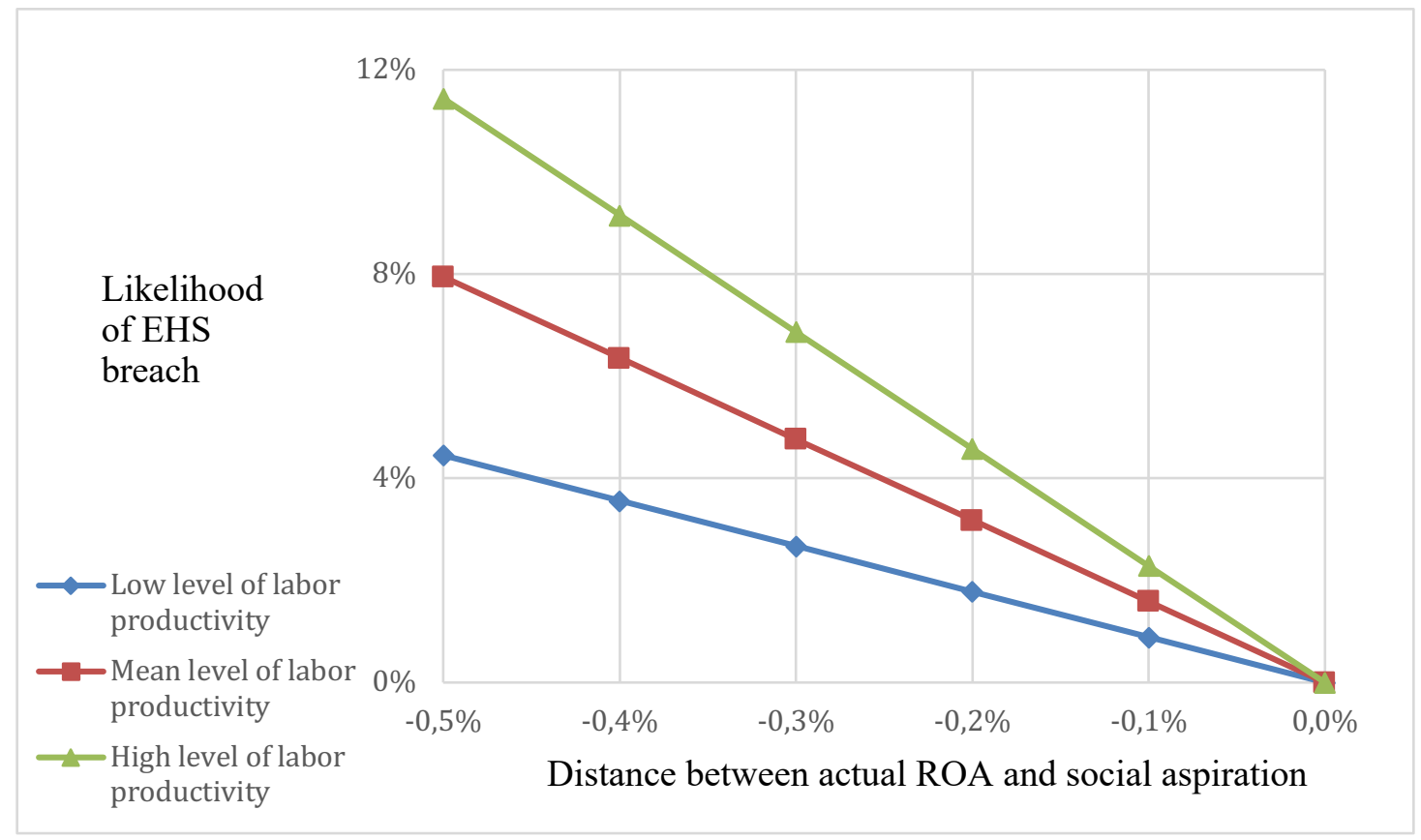

Figure C: Moderating effect of labor productivity on the relationship between ROA (current performance) below social aspiration and the likelihood of EHS breach. (The likelihood of a breach when ROA is at the social aspiration level is benchmarked at zero.)

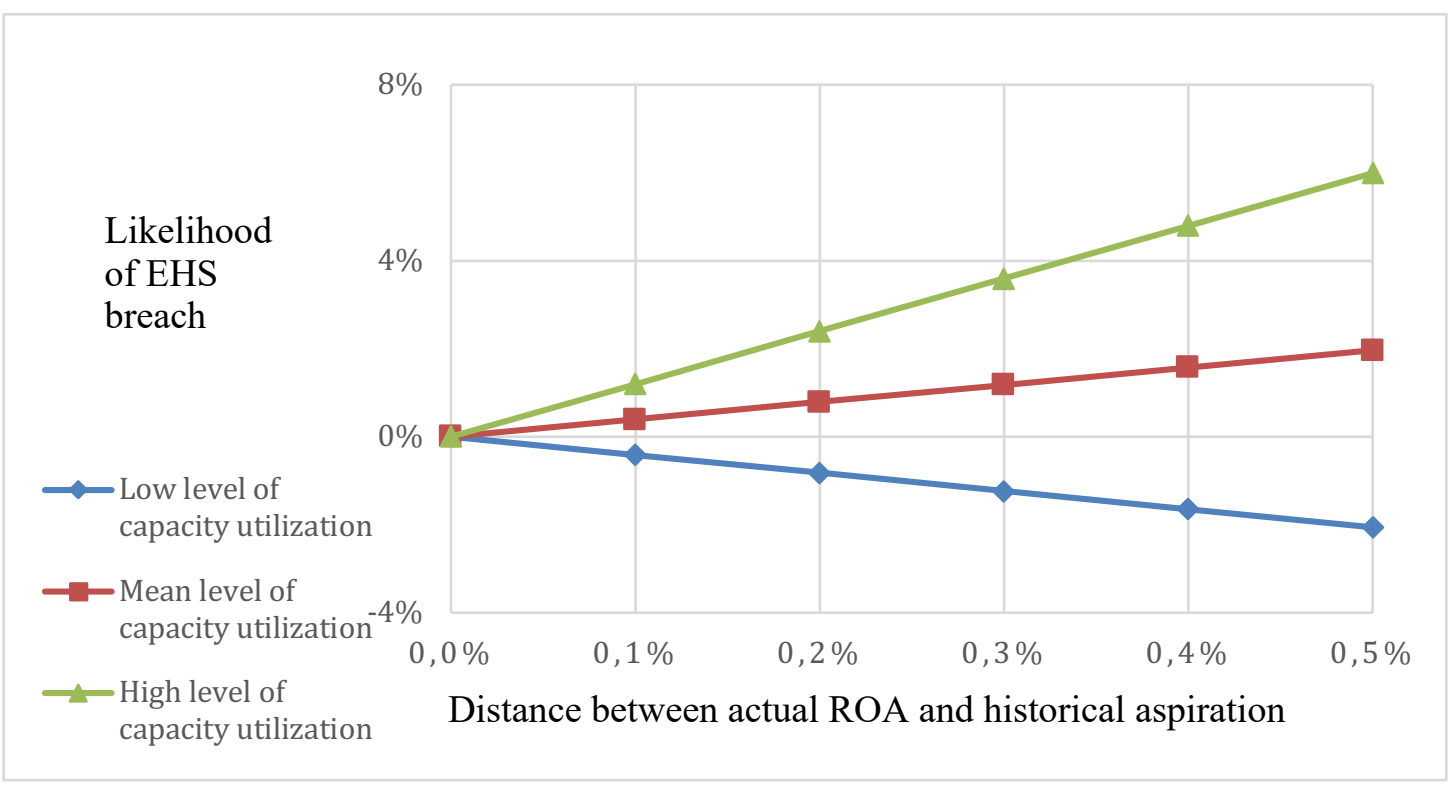

Figure D: Moderating effect of capacity utilization on the relationship between ROA (current performance) above historical aspiration and the likelihood of EHS breach. (The likelihood of a breach when ROA is at the historical aspiration level is benchmarked at zero.) 


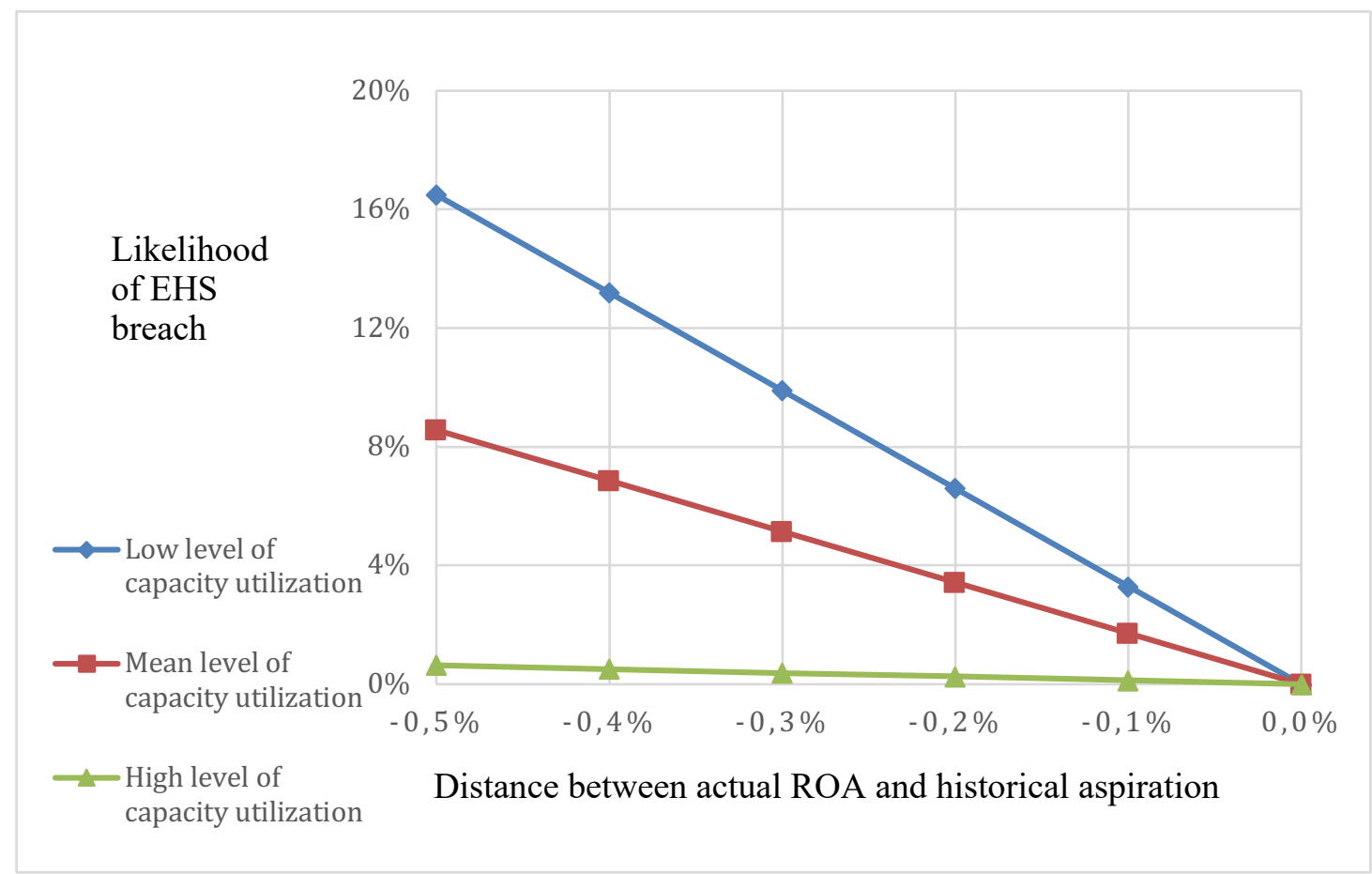

Figure E: Moderating effect of capacity utilization on the relationship between ROA (current performance) below historical aspiration and the likelihood of EHS breach. (The likelihood of a breach when ROA is at the historical aspiration level is benchmarked at zero.)

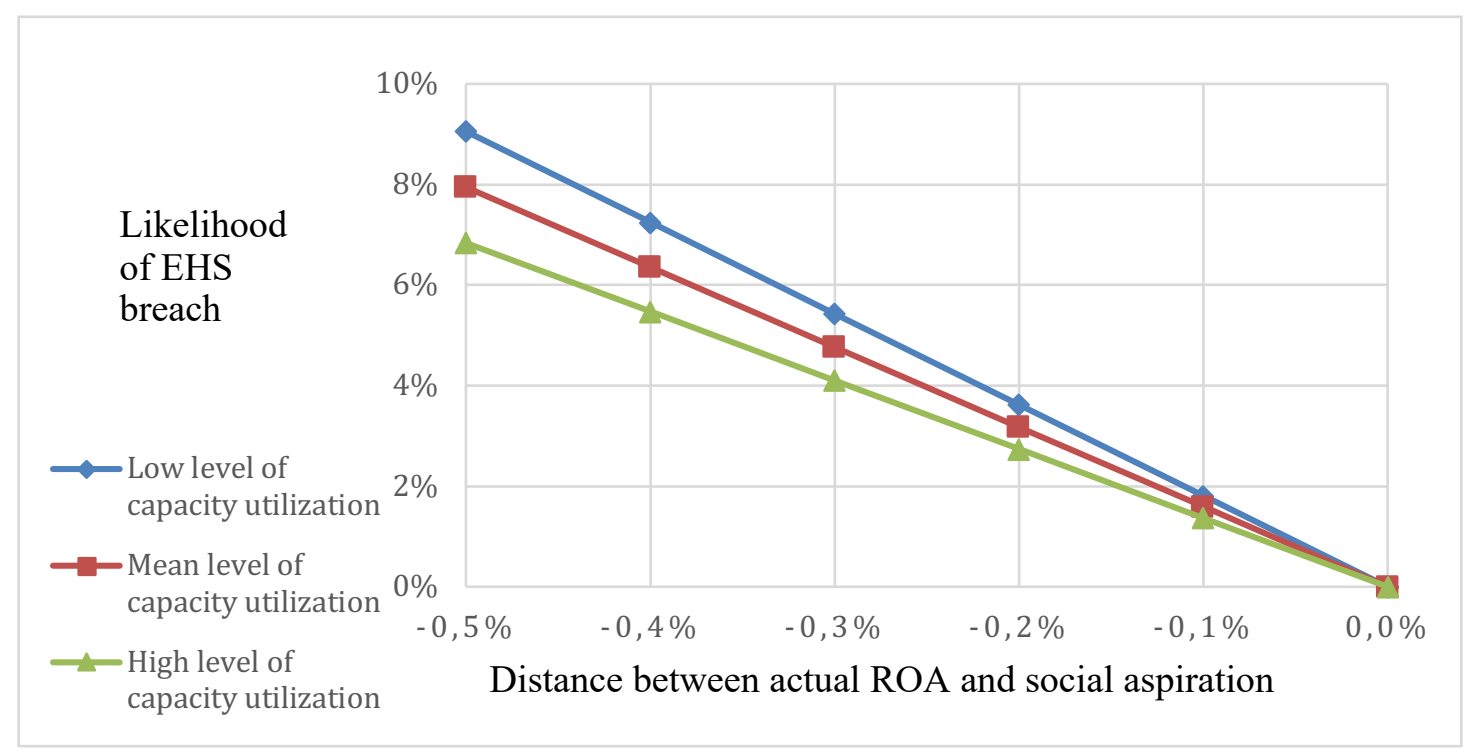

Figure F: Moderating effect of capacity utilization on the relationship between ROA (current performance) below social aspiration and the likelihood of EHS breach. (The likelihood of a breach when ROA is at the historical aspiration level is benchmarked at zero.) 


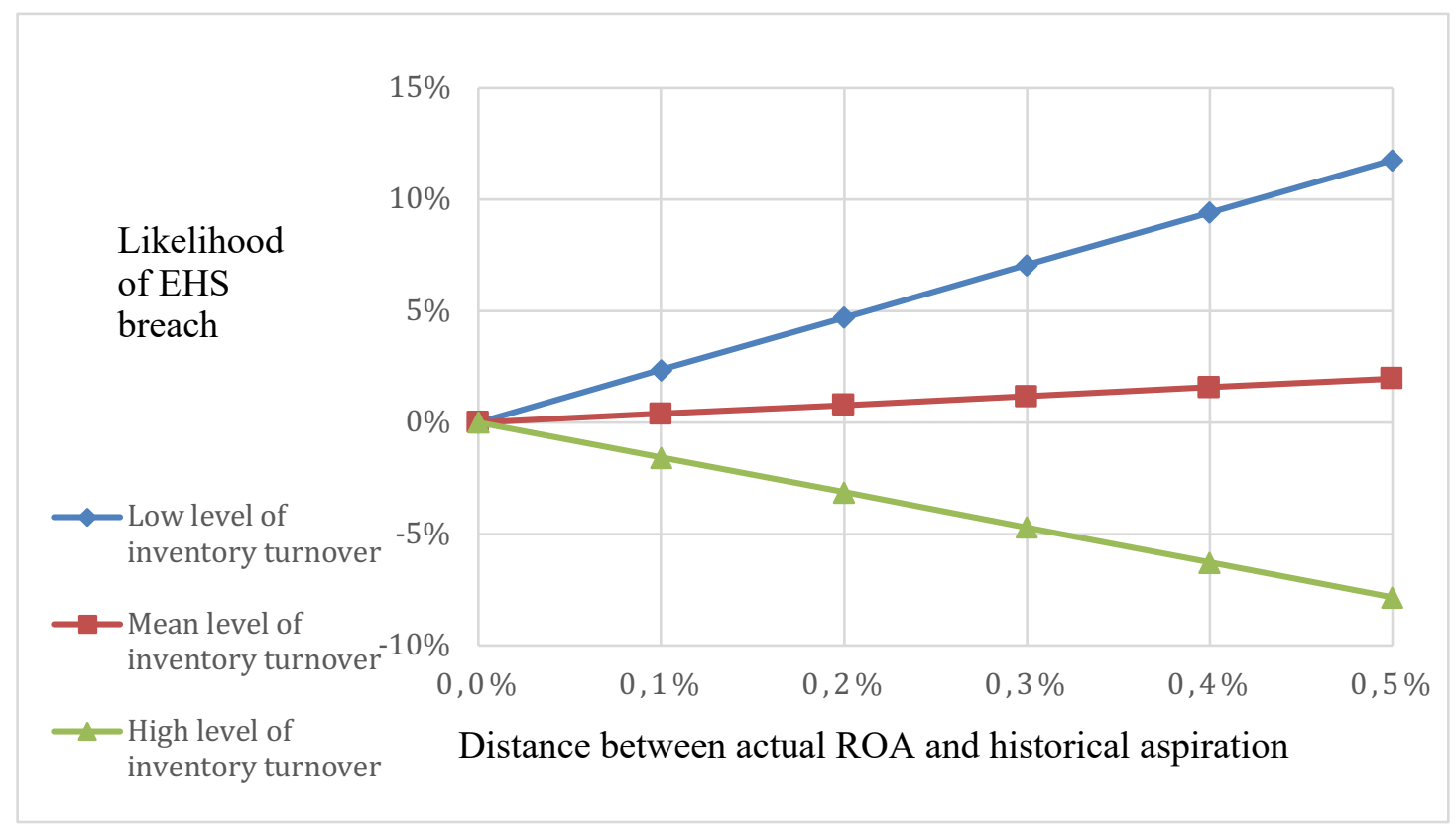

Figure G: Moderating effect of inventory turnover on the relationship between ROA (current performance) above historical aspiration and the likelihood of EHS breach. (The likelihood of a breach when ROA is at the historical aspiration level is benchmarked at zero.) 


\section{Ippendix B}

Table A: Curvilinear relationship between relative performance and breach DV: EHS breach at year $t$

\section{Model 1: Historical aspiration model}

$\mathrm{N}=374$

Coef.

$-4.162 \quad 0.009$

Relative performance (Historical)

$24.745 \quad 0.003$

Squared Relative performance (Historical)

$\mathrm{R}^{2}$

$23.02 \%$

Model 2: Social aspiration model

\begin{tabular}{|l|c|c|}
\hline & Coef. & $\boldsymbol{p}$ \\
\hline Relative performance (Social) & -14.278 & 0.001 \\
\hline Squared Relative performance (Social) & 101.638 & 0.000 \\
\hline $\mathrm{R}^{2}$ & $34.64 \%$ & \\
\hline
\end{tabular}

Note: two-tailed tests; control variables included

Table B: Single breach in each year; multiple breaches in the same firm and year eliminated

\begin{tabular}{|l|c|c|c|c|c|c|c|c|}
\hline \multirow{2}{*}{$\mathrm{N}=342$} & \multicolumn{7}{|c|}{ DV: EHS breach at year $\boldsymbol{t}$} \\
\hline Variables at year t-1 & Coef. & $\boldsymbol{p}$ & Coef. & $\boldsymbol{p}$ & Coef. & $\boldsymbol{p}$ & Coef. & $\boldsymbol{p}$ \\
\hline Below historical aspiration & -10.794 & 0.000 & & & & & & \\
\hline Above historical aspiration & & & 6.987 & 0.006 & & & & \\
\hline Below social aspiration & & & & & -11.876 & 0.001 & & \\
\hline Above social aspiration & & & & & & & 9.486 & 0.000 \\
\hline $\mathrm{R}^{2}$ & $23.02 \%$ & & $21.87 \%$ & & $22.92 \%$ & & $24.07 \%$ & \\
\hline
\end{tabular}

Note: two-tailed tests; control variables included 

Table C: First breach of firms

\begin{tabular}{|l|c|c|c|c|c|c|c|c|}
\hline \multirow{2}{*}{$\mathrm{N}=288$} & \multicolumn{7}{|c|}{ DV: EHS breach at year $\boldsymbol{~}$} \\
\hline Variables at year t-1 & Coef. & $\boldsymbol{p}$ & Coef. & $\boldsymbol{p}$ & Coef. & $\boldsymbol{p}$ & Coef. & $\boldsymbol{p}$ \\
\hline Below historical aspiration & -15.044 & 0.000 & & & & & & \\
\hline Above historical aspiration & & & 7.980 & 0.004 & & & & \\
\hline Below social aspiration & & & & & -9.431 & 0.023 & & \\
\hline Above social aspiration & & & & & & & 11.720 & 0.000 \\
\hline $\mathrm{R}^{2}$ & $27.79 \%$ & & $23.63 \%$ & & $23.15 \%$ & & $26.29 \%$ & \\
\hline
\end{tabular}

Note: two-tailed tests; control variables included

\begin{tabular}{|c|c|c|c|c|c|c|c|c|}
\hline & \multicolumn{8}{|c|}{ DV: EHS breach at year $t(1=$ yes; $0=$ no $)$} \\
\hline & \multicolumn{2}{|c|}{$\begin{array}{l}\text { Model } 1 \\
\text { Relative performance } \\
\text { as ROA below } \\
\text { historical aspiration }\end{array}$} & \multicolumn{2}{|c|}{$\begin{array}{l}\text { Model } 2 \\
\text { Relative performance } \\
\text { as ROA below } \\
\text { social aspiration }\end{array}$} & \multicolumn{2}{|c|}{$\begin{array}{l}\text { Model } 3 \\
\text { Relative performance } \\
\text { as ROA above } \\
\text { historical aspiration }\end{array}$} & \multicolumn{2}{|c|}{$\begin{array}{c}\text { Model } 4 \\
\text { Relative performa } \\
\text { as ROA above } \\
\text { social aspiratio }\end{array}$} \\
\hline Variables at year $\mathrm{t}-1$ & Coef. & $p$ & Coef. & $p$ & Coef. & $p$ & Coef. & \\
\hline ROA below aspiration & -7.588 & 0.611 & -9.998 & 0.002 & & & & \\
\hline ROA above aspiration & & & & & 11.056 & 0.383 & 8.065 & 0.2 \\
\hline Relative performance $\times$ Firm size & -0.403 & 0.881 & -0.018 & 0.051 & -0.812 & 0.723 & 0.919 & 0.4 \\
\hline $\mathrm{R}^{2}$ & $23.17 \%$ & & $20.53 \%$ & & $21.34 \%$ & & $27.08 \%$ & \\
\hline
\end{tabular}

Note: $\mathrm{N}=374$; two-tailed test; control variables included 
Table E: Single-facility firms and multiple-facility firms

\begin{tabular}{|c|c|c|c|c|c|c|c|c|}
\hline \multirow{3}{*}{ Variables at year $\mathrm{t}-1$} & \multicolumn{8}{|c|}{ DV: EHS breach at year $t$} \\
\hline & \multicolumn{8}{|c|}{$\begin{array}{l}\text { Model 1: Single-facility firms } \\
\qquad \mathrm{N}=162\end{array}$} \\
\hline & Coef. & $p$ & Coef. & $p$ & Coef. & $p$ & Coef. & $p$ \\
\hline Below historical aspiration & -14.660 & 0.001 & & & & & & \\
\hline Above historical aspiration & & & 1.961 & 0.571 & & & & \\
\hline Below social aspiration & & & & & -14.720 & 0.002 & & \\
\hline Above social aspiration & & & & & & & 9.236 & 0.007 \\
\hline \multirow[t]{2}{*}{$\mathrm{R}^{2}$} & $15.17 \%$ & & $11.01 \%$ & & $16.27 \%$ & & $14.22 \%$ & \\
\hline & \multicolumn{8}{|c|}{$\begin{array}{l}\text { Model 2: Multiple-facility firms } \\
\qquad \mathrm{N}=212\end{array}$} \\
\hline Variables at year $\mathrm{t}-1$ & Coef. & $p$ & Coef. & $p$ & Coef. & $p$ & Coef. & $p$ \\
\hline Below historical aspiration & 1.441 & 0.678 & & & & & & \\
\hline Above historical aspiration & & & 13.727 & 0.000 & & & & \\
\hline Below social aspiration & & & & & -6.106 & 0.144 & & \\
\hline Above social aspiration & & & & & & & 26.287 & 0.000 \\
\hline $\mathrm{R}^{2}$ & $39.56 \%$ & & $35.43 \%$ & & $29.89 \%$ & & $44.52 \%$ & \\
\hline
\end{tabular}

\begin{tabular}{|c|c|c|c|c|c|c|c|c|c|c|c|}
\hline & & (1) & V: Env & onms & tal bre & at & $\operatorname{ar} t$ & & & & (2) D \\
\hline & & & & & & & & & & & \\
\hline & & & & $=$ ye & $\mathbf{0}=\mathbf{n o}$ & & & & & & \\
\hline Variables at year t-1 & Coef. & $p$ & Coef. & $p$ & Coef. & $p$ & Coef. & $p$ & Coef. & $p$ & Coe \\
\hline $\begin{array}{l}\text { Below historical } \\
\text { aspiration }\end{array}$ & $\begin{array}{c}- \\
31.531\end{array}$ & $\begin{array}{c}0.01 \\
3\end{array}$ & & & & & & & $\begin{array}{c}- \\
12.882\end{array}$ & $\begin{array}{c}0.00 \\
0\end{array}$ & \\
\hline $\begin{array}{l}\text { Above historical } \\
\text { aspiration }\end{array}$ & & & 32.964 & $\begin{array}{c}0.02 \\
6\end{array}$ & & & & & & & 6.49 \\
\hline
\end{tabular}




\begin{tabular}{|l|l|l|l|l|c|c|c|c|c|c} 
Below social aspiration & & & & & $\begin{array}{c}- \\
45.907\end{array}$ & $\begin{array}{c}0.08 \\
1\end{array}$ & & & & \\
\hline Above social aspiration & & & & & & & -0.052 & $\begin{array}{c}0.18 \\
8\end{array}$ & & \\
\hline $\mathrm{R}^{2}$ & $\begin{array}{c}62.91 \\
\%\end{array}$ & & $\begin{array}{c}64.28 \\
\%\end{array}$ & & $\begin{array}{c}62.14 \\
\%\end{array}$ & & $\begin{array}{c}60.35 \\
\%\end{array}$ & & $\begin{array}{c}24.65 \\
\%\end{array}$ & $\begin{array}{c}23.1 \\
\%\end{array}$ \\
\hline
\end{tabular}

Note: two-tailed tests; control variables included

Table G: Conditional logistic regression analysis of EHS breach

DV: EHS breach at year $t(1=$ yes; $0=$ no

\begin{tabular}{|c|c|c|c|c|c|c|}
\hline & \multicolumn{6}{|c|}{ DV: EHS breach at year $t(1=$ yes; $0=$ no } \\
\hline & \multicolumn{2}{|c|}{$\begin{array}{l}\text { Model } 1 \\
\text { Relative performance } \\
\text { as ROA below } \\
\text { historical aspiration }\end{array}$} & \multicolumn{2}{|c|}{$\begin{array}{l}\text { Model } 2 \\
\text { Relative performance } \\
\text { as ROA below } \\
\text { social aspiration }\end{array}$} & \multicolumn{2}{|c|}{$\begin{array}{c}\text { Model } 3 \\
\text { Relative performanc } \\
\text { as ROA above } \\
\text { historical aspiration }\end{array}$} \\
\hline Variables at year $\mathrm{t}-1$ & Coef. & $p$ & Coef. & $p$ & Coef. & $p$ \\
\hline ROA below aspiration & -28.688 & 0.000 & -27.101 & 0.000 & & \\
\hline ROA above aspiration & & & & & 6.950 & 0.15 \\
\hline Relative performance $\times$ Production capacity utilization & 28.826 & 0.019 & 3.792 & 0.000 & 13.627 & 0.01 \\
\hline Relative performance $\times$ Labor productivity & -62.667 & 0.004 & -14.943 & 0.002 & -34.120 & 0.01 \\
\hline Relative performance $\times$ Inventory turnover & 29.416 & 0.099 & -11.959 & 0.001 & -0.255 & 0.96 \\
\hline $\mathrm{R}^{2}$ & $27.26 \%$ & & $22.92 \%$ & & $24.12 \%$ & \\
\hline
\end{tabular}

Note: $\mathrm{N}=374$; two-tailed test; control variables included 


\begin{tabular}{|l|l|c|c|c|c|c|c|c|c|}
\hline Table H: Historical and social aspirational performance consistent firms \\
\hline $\mathrm{N}=240$ & \multicolumn{7}{|c|}{ DV: EHS breach at year $\boldsymbol{t}$} \\
\hline Variables at year t-1 & Coef. & $\boldsymbol{p}$ & Coef. & $\boldsymbol{p}$ & Coef. & $\boldsymbol{p}$ & Coef. & $\boldsymbol{p}$ \\
\hline Below historical aspiration & -12.537 & 0.002 & & & & & & \\
\hline Above historical aspiration & & & 7.410 & 0.013 & & & & \\
\hline Below social aspiration & & & & & -14.103 & 0.002 & & \\
\hline Above social aspiration & & & & & & & 9.648 & 0.006 \\
\hline $\mathrm{R}^{2}$ & $24.18 \%$ & & $23.87 \%$ & & $26.94 \%$ & & $25.98 \%$ & \\
\hline Note: two-tailed tests; control variables included \\
\hline
\end{tabular}

\begin{tabular}{|c|c|c|c|c|c|c|c|c|}
\hline $\mathrm{N}=134$ & \multicolumn{8}{|c|}{ DV: EHS breach at year $t$} \\
\hline Variables at year $\mathrm{t}-1$ & Coef. & $p$ & Coef. & $p$ & Coef. & $p$ & Coef. & $p$ \\
\hline Below historical aspiration & -19.578 & 0.000 & & & & & & \\
\hline Above historical aspiration & & & 7.694 & 0.063 & & & & \\
\hline Below social aspiration & & & & & -21.776 & 0.017 & & \\
\hline Above social aspiration & & & & & & & 14.478 & 0.002 \\
\hline $\mathrm{R}^{2}$ & $40.05 \%$ & & $36.04 \%$ & & $39.77 \%$ & & $39.51 \%$ & \\
\hline
\end{tabular}





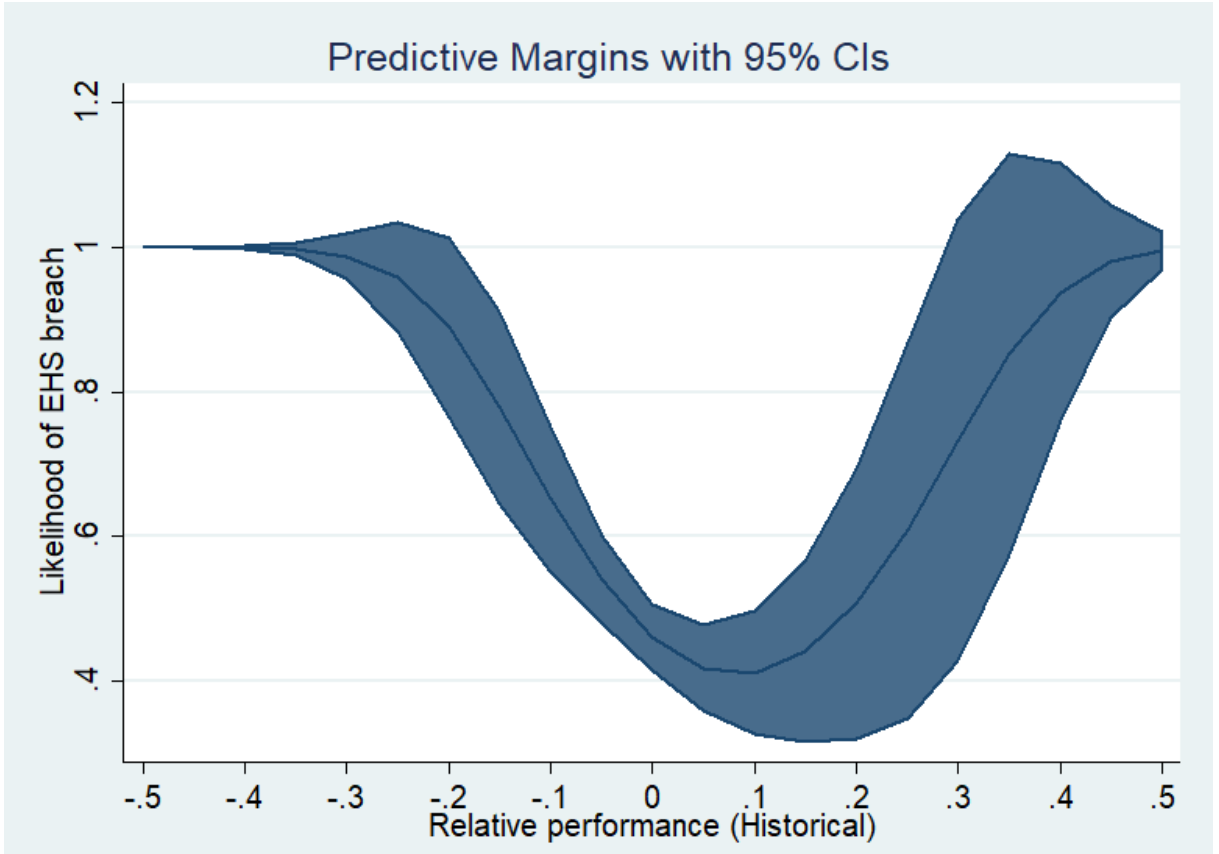

Figure A: Curvilinear relation between historical relative performance and likelihood of EHS breach

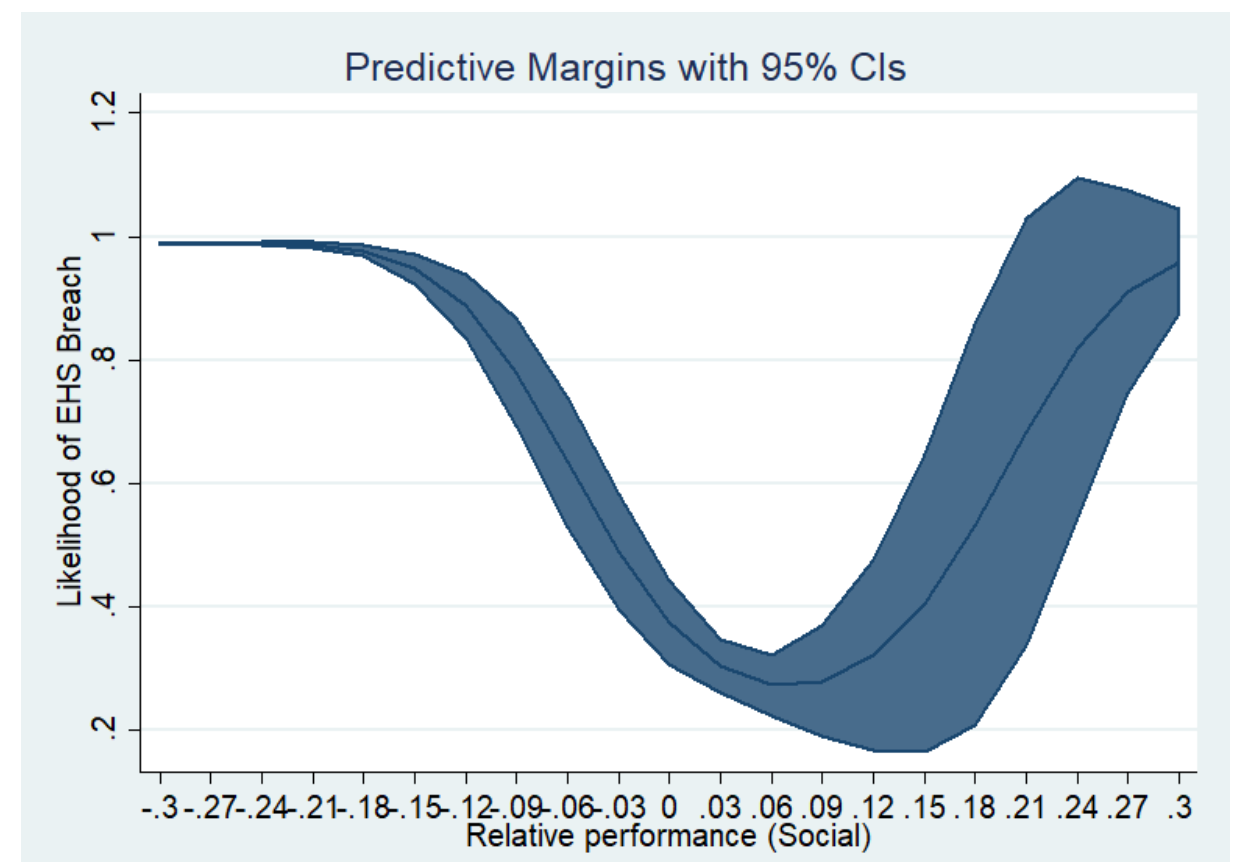

Figure B: Curvilinear relation between social relative performance and likelihood of EHS breach 